\title{
Major Phytocannabinoids and Their Related Compounds: Should We Only Search for Drugs That Act on Cannabinoid Receptors?
}

\author{
Leontina Elena Filipiuc 1,2,+(D), Daniela Carmen Ababei ${ }^{3,+} \mathbb{D}$, Teodora Alexa-Stratulat 1,4, $^{\text {, }}$, \\ Cosmin Vasilica Pricope ${ }^{1,2}\left(\mathbb{D}\right.$, Veronica Bild ${ }^{1,3}$, Raluca Stefanescu ${ }^{1}$, Gabriela Dumitrita Stanciu ${ }^{1, *(D)}$ \\ and Bogdan-Ionel Tamba ${ }^{1,2}$
}

1 Advanced Research and Development Center for Experimental Medicine (CEMEX), Grigore T. Popa University of Medicine and Pharmacy, Universitatii Street, 16, 700115 Iasi, Romania; leontina.filipiuc@umfiasi.ro (L.E.F.); teodora.alexa-stratulat@umfiasi.ro (T.A.-S.); cosmin-vasilica-d-pricope@d.umfiasi.ro (C.V.P.); veronica.bild@gmail.com (V.B.); raluca.stefanescu@umfiasi.ro (R.S.); bogdan.tamba@umfiasi.ro (B.-I.T.)

2 Department of Pharmacology, Clinical Pharmacology and Algesiology, Grigore T. Popa University of Medicine and Pharmacy, Universitatii Street, 16, 700115 Iasi, Romania

3 Pharmacodynamics and Clinical Pharmacy Department, Grigore T. Popa University of Medicine and Pharmacy, Universitatii Street, 16, 700115 Iasi, Romania; dana.ababei@gmail.com

check for updates

Citation: Filipiuc, L.E.; Ababei, D.C.; Alexa-Stratulat, T.; Pricope, C.V.; Bild, V.; Stefanescu, R.; Stanciu, G.D.;

Tamba, B.-I. Major Phytocannabinoids and Their Related Compounds: Should We Only Search for Drugs That Act on Cannabinoid Receptors? Pharmaceutics 2021, 13, 1823. https: / / doi.org/10.3390/ pharmaceutics 13111823

Academic Editors: Yasumasa Ikeda, Javier Garcia-Pardo, Maria Camilla Bergonzi and Charles M. Heard

Received: 10 September 2021

Accepted: 25 October 2021

Published: 1 November 2021

Publisher's Note: MDPI stays neutral with regard to jurisdictional claims in published maps and institutional affiliations.

Copyright: (c) 2021 by the authors. Licensee MDPI, Basel, Switzerland. This article is an open access article distributed under the terms and conditions of the Creative Commons Attribution (CC BY) license (https:// creativecommons.org/licenses/by/ $4.0 /)$.
4 Medical Oncology-Radiotherapy Department, Grigore T. Popa University of Medicine and Pharmacy, University Street, 16, 700115 Iasi, Romania

* Correspondence: gabriela-dumitrita.s@umfiasi.ro

$\dagger$ These authors contributed equally to this work.

\begin{abstract}
The most important discoveries in pharmacology, such as certain classes of analgesics or chemotherapeutics, started from natural extracts which have been found to have effects in traditional medicine. Cannabis, traditionally used in Asia for the treatment of pain, nausea, spasms, sleep, depression, and low appetite, is still a good candidate for the development of new compounds. If initially all attention was directed to the endocannabinoid system, recent studies suggest that many of the clinically proven effects are based on an intrinsic chain of mechanisms that do not necessarily involve only cannabinoid receptors. Recent research has shown that major phytocannabinoids and their derivatives also interact with non-cannabinoid receptors such as vanilloid receptor 1 , transient receptor ankyrin 1 potential, peroxisome proliferator-activated receptor-gamma or glitazone receptor, G55 protein-coupled receptor, and nuclear receptor, producing pharmacological effects in diseases such as Alzheimer's, epilepsy, depression, neuropathic pain, cancer, and diabetes. Nonetheless, further studies are needed to elucidate the precise mechanisms of these compounds. Structure modulation of phytocannabinoids, in order to improve pharmacological effects, should not be limited to the exploration of cannabinoid receptors, and it should target other courses of action discovered through recent research.
\end{abstract}

Keywords: phytocannabinoids; cannabigerol; cannabidiol; tetrahydrocannabinol; synthetic cannabinoids; cannabinoid receptors; endocannabinoid system; pharmacology

\section{Introduction}

\subsection{Phytocannabinoids}

The use of Cannabis has a long history, and the plant has been known for its medicinal and recreational properties for several thousand years [1,2]. There is evidence that Cannabis was cultivated and used for various purposes by many ancient civilizations spread far and wide: the Chinese used it both for infectious and musculoskeletal disorders and to balance and harmonize the mind and the body; the Greeks used it in funeral rituals; Indian warriors consumed it in various forms for its psychoactive and analgesic properties $[3,4]$. 
The Cannabis plant is an annual dioeciously flowering plant, belongs to the Cannabaceae family, and includes the species Sativa, Ruderalis, and Indica. In the Indian Peninsula and Central Asia, it belongs to the indigenous flora, while in the equatorial regions, it does not grow naturally, and thus it is cultivated to be used for different purposes. The two main forms in which Cannabis is used rudimentarily are represented by dried flower bulbs (marijuana) and pieces of resin (hashish) [5].

The unique characteristics of each variety of Cannabis come from the presence of three types of molecules with biological activity: cannabinoids, flavonoids, and terpenoids, which, in different proportions, modulate the potency of the psychoactive effect. The last classification of phytocannabinoids was established in 2012, when it was found that the number of constituents identified in Cannabis was 545, from which more than 100 were phytocannabinoids. These compounds have been isolated from the resin produced by the female plants, of which the most studied are tetrahydrocannabinol (THC, with the two major compounds $\triangle 8$-THC and $\triangle 9$-THC), cannabidiol (CBD), and cannabigerol (CBG) $[6,7]$. The other natural cannabinoids derived from $C$. sativa are classified into seven more classes: cannabinol (CBN), cannabichromene (CBC), cannabinodiol (CBND), cannabielsoin (CBE), cannabicyclol (CBL), cannabitriol (CBT), and miscellaneous types [8].

Phytocannabinoid compounds have a common chemical characteristic, which is the terpeno-phenolic structure with 21 carbon atoms. This group is further classified into 11 different subclasses listed in Table 1.

Table 1. Classification of phytocannabinoids. Adapted from [9], MDPI, 2021.

\begin{tabular}{|c|c|c|c|}
\hline Class of Compounds & $\begin{array}{c}\text { The Number of } \\
\text { Compounds in Each Class }\end{array}$ & $\begin{array}{c}\text { The First Representative Compound } \\
\text { of the Class }\end{array}$ & $\begin{array}{l}\text { Chemical Structure of the } \\
\text { Representative Compound }\end{array}$ \\
\hline $\begin{array}{l}\Delta 9 \text {-trans- } \\
\text { tetrahydrocannabinol }\end{array}$ & 25 & $\begin{array}{c}\Delta 9-\mathrm{THC} \text {-isolated in } 1964 \text { by Goani and } \\
\text { Mecholum using chromatography } \\
\text { techniques [10] }\end{array}$ & \\
\hline $\begin{array}{l}\Delta 8 \text {-trans- } \\
\text { tetrahydrocannabinol }\end{array}$ & 5 & $\begin{array}{c}\Delta 8 \text {-THC-isolated in Maryland in } 1966 \\
{[11]}\end{array}$ & \\
\hline cannabidiol & 10 & $\begin{array}{l}\text { CBD-C5-isolated in } 1940 \text { from native } \\
\text { Minnesota hemp [12] }\end{array}$ & \\
\hline cannabigerol & 16 & $\begin{array}{l}\text { CBG-isolated in } 1964 \text { using florisil } \\
\text { chromatography [13] }\end{array}$ & \\
\hline
\end{tabular}


Table 1. Cont.

\begin{tabular}{|c|c|c|c|}
\hline Class of Compounds & $\begin{array}{l}\text { The Number of } \\
\text { Compounds in Each Class }\end{array}$ & $\begin{array}{c}\text { The First Representative Compound } \\
\text { of the Class }\end{array}$ & $\begin{array}{l}\text { Chemical Structure of the } \\
\text { Representative Compound }\end{array}$ \\
\hline cannabichromene & 9 & CBC_-isolated in 1966 by Gaoni Y. [14] & \\
\hline cannabinol & 11 & $\begin{array}{l}\text { CBN synthesized by Adams et al. in the } \\
\text { US and by Todd's group in the UK in } \\
1940[15,16]\end{array}$ & \\
\hline cannabinodiol & 2 & $\begin{array}{l}\text { CBND-C3-isolated in } 1973 \text { [17] } \\
\text { CBND-C5-isolated in } 1977 \text { [18] }\end{array}$ & \\
\hline cannabicyclol & 3 & $\begin{array}{c}\text { CBL-compound was isolated by Korte } \\
\text { and Sieper in 1964, and the structure } \\
\text { was elucidated by Crombie et al. in } 1968 \\
{[19,20]}\end{array}$ & \\
\hline cannabielsoin & 5 & $\begin{array}{l}\text { CBE-C5-isolated in } 1973 \text { from } \\
\text { Lebanese hashish [21] }\end{array}$ & \\
\hline cannabitriol & 9 & $\begin{array}{l}\text { CBT-C5-isolated in } 1966 \text { from Japanese } \\
\text { hemp, but the complete chemical } \\
\text { structure was established } 10 \text { years later } \\
\qquad[21,22]\end{array}$ & \\
\hline $\begin{array}{l}\text { other unclassified types } \\
\text { of cannabinoids }\end{array}$ & 30 & $\begin{array}{l}\text { The first ones isolated in } 1975 \text { (examples: } \\
\text { dehydrocannabifuran DCBF-C5, } \\
\text { cannabifuran CBF-C5) [23] }\end{array}$ & \\
\hline
\end{tabular}

The discovery of these compounds led to the identification of cannabinoid receptors (CB1 and CB2) and endogenous ligands of the endocannabinoid system. There is evidence that this system plays an essential role in many normal physiological processes, such as memory, cognition, learning, motor control, anxiety, appetite, sleep, lipogenesis, fertility, formation of insulin and muscle fibers, vasomotricity, intestinal and bronchial motility, and immune modulation, but also in pathological-like pain, inflammation, and cancer [24-42].

The type of effect, either beneficial or harmful, was considered to be given by the way a compound acts on CB receptors (stimulation or inhibition) and by the substances individual affinity for a certain type of receptor. However, an increasing amount of data suggest that cannabinoids can interact with several types of receptors, thus potentially 
explaining the plethora of effects noted in preclinical and clinical studies. As such, potential new drugs should be assessed by means of more complex tests, and new methods for identifying target receptors should be used [24].

\subsection{The Endocannabinoid System}

Despite the initial beliefs that cannabinoids have non-specific binding sites due to their lipophilic nature, research in the area of mapping binding sites has identified several $\mathrm{G}$ protein-coupled receptors that interact with cannabinoids, two of which have been studied extensively and are considered canonical receptors: cannabinoid receptor 1 (CB1R) and cannabinoid receptor 2 (CB2R) [24]. Additionally, several endogenous ligands of the cannabinoid receptors have also been identified, 2-arachidonoylglycerol (2-AG) and $\mathrm{N}$-arachidonoylethanolamine (anandamide) (AEA) being the best-known signaling lipids of this class. As such, it is currently widely accepted that the endocannabinoid system consists of cannabinoid receptors, endogenous cannabinoids, and enzymes responsible for endocannabinoid synthesis, transport, and degradation [43].

Cannabinoid receptors are widely expressed in different tissues and organs, including, but not limited to, the liver, the pancreas, the gonads and gametes, the skeletal muscle, the adipose tissue, and the skin [44-48]. However, the highest concentration of CB1R can be found in the nervous system-CB1R is highly expressed on glutamatergic, cholinergic, glycinergic, and serotonergic neurons, especially on synaptic terminals. Although not as abundant, CB2R can also be found in the CNS, especially in microglia and other cells of immune origin [49]. This wide distributon of cannabinoid receptors suggests that the endocannabinoid system is extremely complex and multifunctional, interacting with several different signaling pathways (including the dopamine and opioid pathways) and modulating a plethora of endogenous processess. Another interesting trait of CB1R that contributes to the system's complexity is that, although CB1R is primarily expressed in the cell membrane, distinct CB1R subpopulations exist within the cell, most notably in lysosomes and in mitochondria [50], thus pointing towards a potential involvement of the cannabinoid system in even more pathological conditions than previousely suggested. Additionally, a recent body of evidence has pointed towards these receptors' ability to form homo- and heterodimers with several types of receptors such as mu-opioid, dopamine, or adenosine A2 receptors [51], thus further increasing the complexity of the system. Of note, endocannabinoids interact with the two specific receptors described above, via the G protein, but also interact with non-cannabinoid receptors such as vanilloid receptor 1 (TRPV1), previously referred to as capsaicin receptor, transient receptor potential ankyrin 1 (TRPA1), and G55 protein-coupled receptor (GPR55), and nuclear receptors peroxisome proliferator-activated receptor alpha PPAR $\alpha$ and peroxisome proliferator-activated receptor gamma (PPAR $\gamma$ or PPRARG) [26,52].

There are numerous reports regarding the biological changes that occur after administering CB1R agonists, most of which have concluded that the effects are biphasic and pleomorphic [53]. This is a two-edged sword, since the abundance of CB1Rs throughout the body is probably associated with diverse side effects that could affect various tissues and systems - the systematic activation of CB1R has been asociated with cardiovascular, digestive, and neurological side effects. As such, aiming to modulate receptor affinity and to identify as many binding sites as possible for exocannabinoids could prove to have immense therapeutic potential. It is widely agreed that CB1R binding is responsible for the cannabinoids' psychotropic effect, which is why, in recent years, an important part of research has focused on binding CB2R with the aim of modulating pain and inflammation [54].

The second component of the endocannabinoid system consists of the CB1R and $\mathrm{CB} 2 \mathrm{R}$ endogenous ligands. The first endogenous cannabinoid to be discovered was AEA, shortly followed by 2-AG. Despite additional data that have shown there are several other endogenous peptides and arachidonic acid derivatives that bind to CB receptors [55], most research in the field is still focused on the two aforementioned agonists. AEA is a high- 
affinity partial agonist of CB1R that has little to no effect on CB2R. Available data indicate it has a cannabinomimetic effect and modulates several essential processes both in the central nervous system and in the periphery [56]. It is synthesized in an on-demand manner, the best-known trigger for synthesis being an increase in intracellular Ca2 ${ }^{+}$concentrations [57] following a postsynaptic neuronal depolarization [58,59], as suggested by in vitro and in vivo experiments performed in the nucleus accumbens core [60]. 2-AG is a moderateaffinity full agonist of both CB1R and CB2R whose baseline levels seem to be higher than those of AEA in several tissues such as brain, spleen, or liver tissue [59]. One of its main roles involves regulating neurotransmitter release in different neurocognitive processes such as emotion and pain sensation [61]. Although there is still controversy regarding the synthesis of 2-AG, it appears it is also an on-demand Ca-dependent system similar to that of AEA. Both AEA and 2-AG levels can be modulated by several endogenous and exogenous factors such as chronic stress exposure, cortisone treatment, fasting, starvation, and pain $[58,62]$.

Although not yet completely elucidated, the sum of enzymes and peptides involved in the synthesis, transport, and degradation of endocannabinoids and their receptors also plays an important role in this system and deserves more attention in that the modulation of the endocannabinoid tone is responsible for the main positive/negative effects on health. Among the best studied elements are N-acylphosphatidylethanolamine phospholipase, phospholipase $C$, diacylglycerol, lipase $\alpha$ or $\beta$, fatty acid amide hydrolase, and monoacylglycerol lipase [26,63].

\section{Major Phytocannabinoids: Cannabigerol-, Cannabidiol-, and Tetrahydrocannabinol-Type Compounds}

\subsection{Structure-Affinity Relationship of Cannabinoid Receptors}

The present section aims to provide information on the influence of different substituents of the resorcinyl moiety on the affinity of phytocannabinoids toward human cannabinoid receptors 1 and 2 .

Taking into consideration the high number of phytocannabinoids described in the scientific literature [64], only the binding affinities of the compounds included in the cannabigerol-type compounds, cannabidiol-type compounds, and tetrahydrocannabinoltype compounds are presented in the following paragraphs. Additionally, another limitation commonly encountered in this research field is that only few studies contain the determination of the binding affinities of multiple cannabinoids using identical assay conditions within the same laboratory [65-69]. These studies employ a synthetic cannabimimetic compound denoted as CP55940 prepared as radioligand $\left[{ }^{3} \mathrm{H}\right] \mathrm{CP} 55940$ which possesses a high affinity for CB1 and CB2 receptors (Figure 1). Cellular membranes containing either CB1 or CB2 receptors obtained from different cellular cultures were used to assess the affinity constant of phytocannabinoids based on radioligand displacement.

For tetrahydrocannabinol-type compounds, $\Delta 9$-trans-tetrahydrocannabivarin containing a three-carbon alkylic substituent of the resorcinyl moiety instead of the five-carbon substituent of $\Delta 9$-trans-tetrahydrocannabinol showed a slightly increased affinity toward CB1 and a slightly diminished affinity toward CB2 [65]. The carboxyl group present in the natural compound $\Delta$ 9-trans-tetrahydrocannabinolic acid $\mathrm{A}$, adjacent to the hydroxyl group, causes a decrease in the affinity toward CB1 and raises the affinity toward CB2 [65].

Within the cannabigerol class of phytocannabinoids, one of the following changes leads to a decrease in the affinity of the compound in comparison with cannabigerol: (i) reduction in the alkylic side chain from five to three carbon atoms, (ii) the presence of the carboxyl group adjacent to the hydroxyl group of the resorcinyl moiety, and (iii) the presence of the methoxy moiety [67]. 

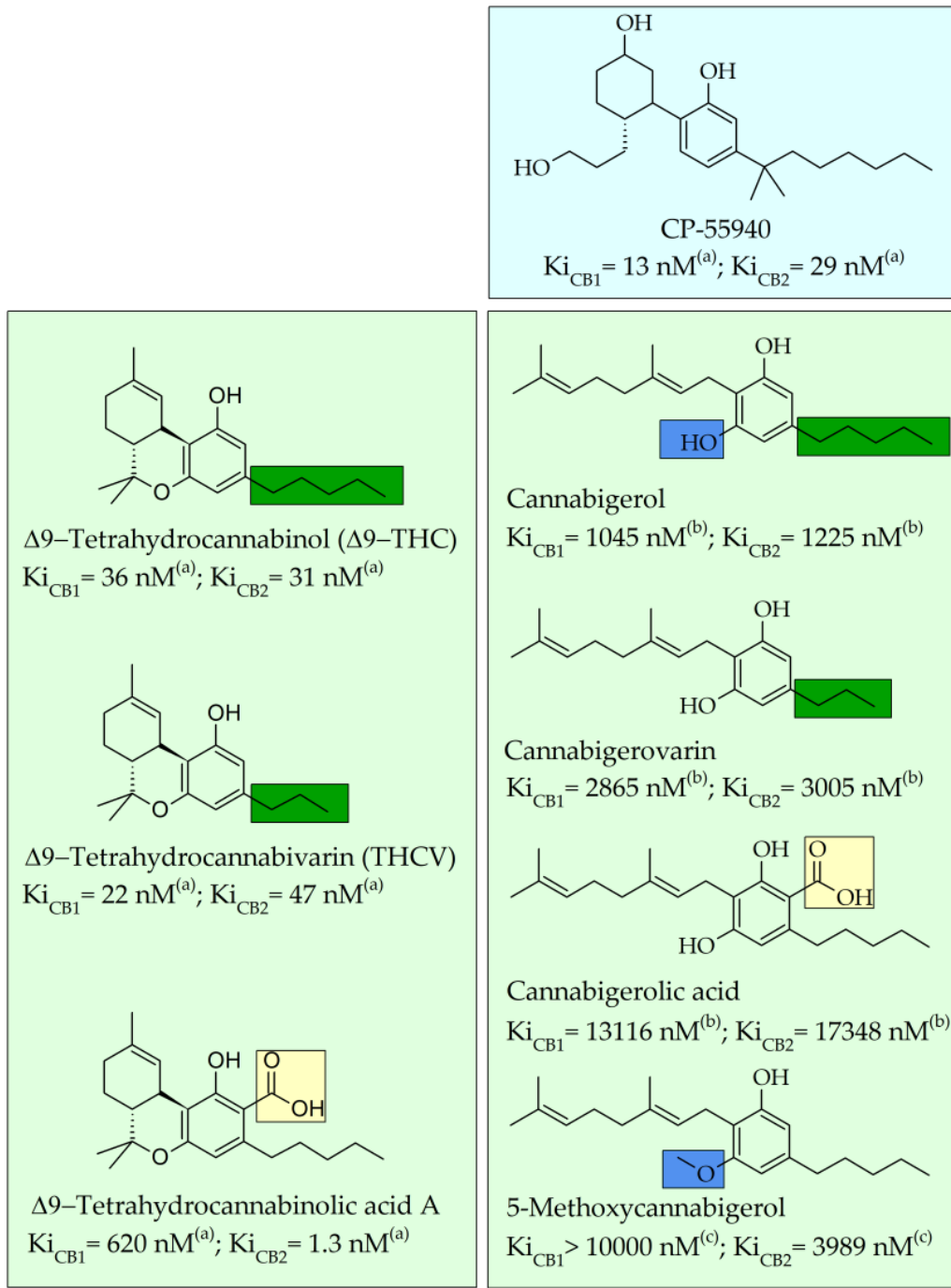

Cannabigerol

$\mathrm{Ki}_{\mathrm{CB} 1}=1045 \mathrm{nM}^{(\mathrm{b})} ; \mathrm{Ki}_{\mathrm{CB} 2}=1225 \mathrm{nM}^{(\mathrm{b})}$

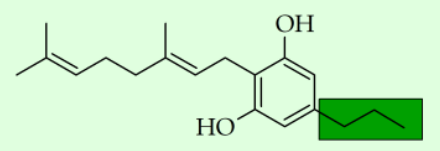

Cannabigerovarin

$\mathrm{Ki}_{\mathrm{CB} 1}=2865 \mathrm{nM}^{(\mathrm{b})} ; \mathrm{Ki}_{\mathrm{CB} 2}=3005 \mathrm{nM}^{(\mathrm{b})}$

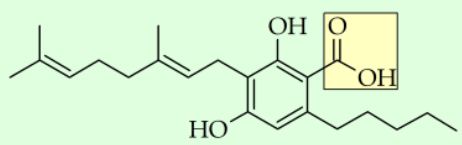

Cannabigerolic acid

$\mathrm{Ki}_{\mathrm{CB} 1}=13116 \mathrm{nM}^{(\mathrm{b})} ; \mathrm{Ki}_{\mathrm{CB} 2}=17348 \mathrm{nM}^{(\mathrm{b})}$

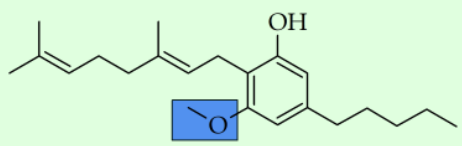

5-Methoxycannabigerol

$\mathrm{Ki}_{\mathrm{CB} 1}>10000 \mathrm{nM}^{(\mathrm{c})} ; \mathrm{Ki}_{\mathrm{CB} 2}=3989 \mathrm{nM}^{(\mathrm{c})}$

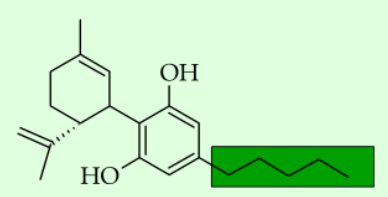

Cannabidiol

$\mathrm{Ki}_{\mathrm{CB} 1}=1690 \mathrm{nM}^{(\mathrm{b})} ; \mathrm{Ki}_{\mathrm{CB} 2}=1714 \mathrm{nM}^{(\mathrm{b})}$

$\mathrm{Ki}_{\mathrm{CB} 1}=200 \mathrm{nM}^{(\mathrm{a})} ; \mathrm{Ki}_{\mathrm{CB} 2}=240 \mathrm{nM}^{(\mathrm{a})}$

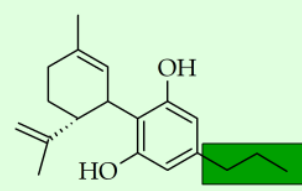

Cannabidivarin

$\mathrm{Ki}_{\mathrm{CB} 1}=14445 \mathrm{nM}^{(\mathrm{b})} ; \mathrm{Ki}_{\mathrm{CB} 2}=15719 \mathrm{nM}^{(\mathrm{b})}$

$\mathrm{Ki}_{\mathrm{CB} 1}>10000 \mathrm{nM}^{(\mathrm{a})} ; \mathrm{Ki}_{\mathrm{CB} 2}=140 \mathrm{nM}^{(\mathrm{a})}$

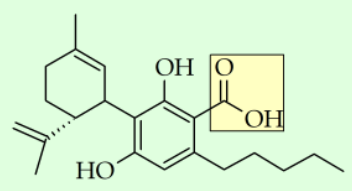

Cannabidiolic acid

$\mathrm{Ki}_{\mathrm{CB} 1}=626 \mathrm{nM}^{(\mathrm{b})} ; \mathrm{Ki}_{\mathrm{CB} 2}=813 \mathrm{nM}^{(\mathrm{b})}$

$\mathrm{Ki}_{\mathrm{CB} 1}>10000 \mathrm{nM}^{(\mathrm{a})} ; \mathrm{Ki}_{\mathrm{CB} 2}=12 \mathrm{nM}^{(\mathrm{a})}$

Figure 1. Chemical structures and binding affinities of ten major phytocannabinoids able to cause, in vitro, the displacement of synthetic $\left[{ }^{3} \mathrm{H}\right] \mathrm{CP} 55940$ bound to human cannabinoid receptors 1 or 2 both embedded in cellular membranes. The binding affinities are reported according to the published data available in the following scientific articles: ${ }^{a}$ [65]; ${ }^{b}$ [70]; ${ }^{c}$ [68].The chemical structures were prepared with $\mathrm{ACD} / \mathrm{ChemSketch}$, and the three classes of phytocannabinoids are included in separate inserts. The substituents of the resorcinyl moiety whose replacements cause a change in affinity constants (Ki) are highlighted.

The analysis of the major compounds from the cannabidiol class indicates the results of different studies are difficult to correlate, probably due to the difference in the assay conditions. However, a decrease in the affinity for CB1 can be observed for canabidivarin and cannabidiolic acid in comparison with cannabidiol [65,67].

Taking into account these results, the most likely model of interaction between phytocannabinoids and cannabinoid receptors CB1 and CB2 involves noncovalent phenyl-phenyl interaction between the resorcinyl moiety and a phenylalanine residue present in the active site of the cannabinoid receptors. Delocalization of the $\pi$-electrons of the resorcinyl moiety would be the cause of the strong effect of lowering the affinity for CB1 in the case of carboxylic phytocannabinoids. This model agrees with the recent $\mathrm{X}$-ray crystallography data on the CB1 structure [71]. 


\subsection{Pharmacological Effects}

In preclinical and clinical studies, phytocannabinoids have shown pleiotropic effects resulting in diverse clinical applications. Table 2 summarizes all the data related to different tested targets for each family of compounds (CBG, CBD, THC).

Table 2. Major cannabinoid targets.

\begin{tabular}{|c|c|c|c|c|c|}
\hline Class & Compounds & Targets & Effects & Potential Use as/in & References \\
\hline \multirow{21}{*}{ CBG } & \multirow{10}{*}{ CBG } & CB1 & Poor agonist & & [70] \\
\hline & & CB2 & Partial agonist & & [70] \\
\hline & & TRPM8 & Antagonist & Prostatic cancer & [72] \\
\hline & & TRPV1 & Stimulation & $\begin{array}{l}\text { Pain and inflammation, } \\
\text { breast, skin, colon cancer }\end{array}$ & {$[72]$} \\
\hline & & $\begin{array}{c}\alpha 2- \\
\text { Adrenoceptor }\end{array}$ & Agonist & Anti-inflammatory & {$[25,73]$} \\
\hline & & IL-1 $\beta$ & \multirow{4}{*}{ Reduction } & \multirow{5}{*}{ Neuroinflammation } & \multirow{5}{*}[74]{} \\
\hline & & TNF- $\alpha$ & & & \\
\hline & & IFN- $\gamma$ & & & \\
\hline & & PPAR- $\gamma$ & & & \\
\hline & & Nrf-2 levels & Upregulation & & \\
\hline & CBG, cyclic CBG & TRPA1 & Activation & $\begin{array}{c}\text { Analgesic, } \\
\text { anti-inflammatory }\end{array}$ & {$[75]$} \\
\hline & \multirow{4}{*}{ CBG, CBGV, CBGA } & $\begin{array}{l}\text { TRPV3 } \\
\text { TRPV4 }\end{array}$ & Activation and desensitization & $\begin{array}{l}\text { Anti-inflammatory agent } \\
\text { in IBD }\end{array}$ & [76] \\
\hline & & $\begin{array}{c}\text { iNOS } \\
\text { expression }\end{array}$ & Reduction & \multirow{3}{*}{ Anti-inflammatory } & \multirow{3}{*}[77]{} \\
\hline & & SOD & $\begin{array}{c}\text { Increased } \\
\text { activity }\end{array}$ & & \\
\hline & & Cytokines & Downregulation & & \\
\hline & \multirow{3}{*}{ CBG, CBGA } & $\mathrm{COX}-1, \mathrm{COX}-2$ & Inhibition & \multirow{3}{*}{ Anti-inflammatory } & \multirow{3}{*}{ [78] } \\
\hline & & PLA2 & Inhibition & & \\
\hline & & MAGL & Inhibition & & \\
\hline & \multirow{2}{*}{$\begin{array}{c}\text { CBG } \\
\text { CBGA }\end{array}$} & ALR & Inhibition & \multirow{2}{*}{ Diabetic complications } & [79] \\
\hline & & $\operatorname{PPAR} \alpha / \gamma$ & Full or partial agonist & & [80] \\
\hline & CBGV & TRPV2 & Antagonist & Cancer & {$[72,81]$} \\
\hline \multirow{9}{*}{ CBD } & \multirow{4}{*}{ CBD } & CB1 & Activation & Chronic neuropathic pain & {$[82,83]$} \\
\hline & & TRPV1 & Agonist & \multirow{3}{*}{ Depression } & \multirow{3}{*}[84,85]{} \\
\hline & & 5HT1A & Agonist & & \\
\hline & & $\operatorname{PPAR} \gamma$ & Agonist & & \\
\hline & \multirow{5}{*}{ CBDV } & $\mathrm{CB} 1 / \mathrm{CB} 2$ & $\begin{array}{c}\text { Indirect } \\
\text { inhibition }\end{array}$ & & [86] \\
\hline & & TRPA1 & Stimulation & & [72] \\
\hline & & TRPV1 & Desensitization & & [87] \\
\hline & & TRPV2 & Stimulation & & [88] \\
\hline & & GPR55 & Antagonist & $\begin{array}{l}\text { Dravet syndrome, } \\
\text { anticonvulsant }\end{array}$ & {$[87,89]$} \\
\hline
\end{tabular}


Table 2. Cont.

\begin{tabular}{|c|c|c|c|c|c|}
\hline Class & Compounds & Targets & Effects & Potential Use as/in & References \\
\hline & & GPR6 & $\begin{array}{l}\text { Inverse } \\
\text { agonist }\end{array}$ & & {$[90]$} \\
\hline & & $\mathrm{DAGL} \alpha$ & Inhibition & & [86] \\
\hline & & AEA & $\begin{array}{l}\text { Inhibition of cellular } \\
\text { uptake }\end{array}$ & & [86] \\
\hline & & IL-1 $\beta$ & Reduction & IBD & [91] \\
\hline & \multirow{2}{*}{ CBDA } & 5HT1A & Activation & Nausea & {$[92,93]$} \\
\hline & & $\begin{array}{l}\text { cAMP protein } \\
\text { kinase A }\end{array}$ & Inhibition & Breast cancer & {$[94]$} \\
\hline \multirow{11}{*}{$\mathrm{THC}$} & \multirow{8}{*}{$\Delta 9-\mathrm{THC}$} & \multirow{2}{*}{ CB1/CB2 } & Activation & Anti-inflammatory & [95] \\
\hline & & & Mixed modulation & Alzheimer & {$[96,97]$} \\
\hline & & MDSCs & Induction & Anti-inflammatory & [98] \\
\hline & & AchE & Inhibition & Alzheimer & [99] \\
\hline & & Amyloid- $\beta$ & Reduction & Alzheimer & {$[100]$} \\
\hline & & TRPV2 & Agonist & & {$[101,102]$} \\
\hline & & TRPV3 & Agonist & & {$[76,101]$} \\
\hline & & TRPV3 & Agonist & & {$[76,101]$} \\
\hline & $\triangle 8-\mathrm{THC}$ & CB1 & Antagonist & Anti-inflammatory & {$[103]$} \\
\hline & & $\mathrm{CB} 2$ & Partial agonist & Mood disorders & [103] \\
\hline & THCA-A & $\operatorname{PPAR} \gamma$ & Stimulation & Obesity & {$[104]$} \\
\hline
\end{tabular}

CBG, cannabigerol; CB1, cannabinoid receptor 1; CB2, cannabinoid receptor 1; TRPM8, Transient Receptor Potential Melastatin-8; TRPV1, vanilloid receptor $1 ; \alpha 2$-Adrenoceptor, alpha-2-Adrenoceptor; IL-1 $\beta$, interleukin- $1 \beta$; TNF- $\alpha$, tumor necrosis factor alpha; IFN- $\gamma$, interferon gamma; PPAR- $\gamma$, peroxisome proliferator-activated receptor gamma; Nrf-2 levels, nuclear factor E2-related factor 2; TRPA1, transient receptor potential ankyrin 1; TRPV3, transient receptor potential vanilloid-3; TRPV4, transient receptor potential vanilloid-type 4; iNOS expression, inducible nitric oxide synthase expression; CBGV, cannabigerovarin; CBGA, cannabigerolic acid; COX-1, COX-2, Cyclooxygenase-1, Cyclooxygenase-2; SOD, superoxide dismutase; PLA2, Phospholipase A2; MAGL, monoacylglycerol lipase; PPAR $\alpha / \gamma$, peroxisome proliferator-activated receptors $\alpha / \gamma$; GPR55, G protein-coupled receptor 55; CBDV, cannabidivarin; TRPV2, transient receptor potential vanilloid 2; GPR6, G Protein-Coupled Receptor 6; DAGL $\alpha$, diacylglycerol lipase-alpha; AEA, N-arachidonoylethanolamine (anandamide); 5HT1A, 5-hydroxytryptamine receptor 1A; cAMP protein kinase A, cyclic adenosine monophosphate protein kinase A; THC, tetrahydrocannabinol; $\triangle 9$-THC, $\Delta$ 9-trans-tetrahydrocannabinol; MDSCs, myeloid-derived suppressor cells; AchE, acetylcholinesterase; $\Delta 8$-THC, $\Delta 8$-trans-tetrahydrocannabinol; THCA-A, tetrahydrocannabinolic acid; IBD, inflammatory bowel disease.

Moreover, these three major families of compounds studied preclinically or in clinical trials in different pathologies are shown in Tables 3 and 4.

\subsubsection{Cannabigerol (CBG)-Type Compounds}

Cannabigerol-type compounds represent one of the most structurally diverse classes of phytocannabinoids, being the second most abundant in the Cannabis plant, making up $16.3 \%$ of the phytocannabinoid content, with the most important compounds being represented by: cannabigerol (CBG), cannabigerolic acid (CBGA), cannabigerovarin (CBGV), cannabigerovarinic acid (CBGVA), ortho-methyl cannabigerol, and cannabigerolic acid methyl ether [8].

Cannabigerol (CBG), a minor cannabinoid present in small amounts $(<1 \%)$ in the Cannabis plant, serves as the direct precursor to cannabidiol (CBD) and tetrahydrocannabinol (THC), and it was the first natural cannabinoid to be synthesized [64]. The compound was purified from Cannabis in the same year as THC (1964) by Gaoni and Mechoulam, and, soon enough, it was found that CBG does not have the same psychotropic effects as THC [105].

Cannabigerolic acid (CBGA) is one of many minor cannabinoids produced by the Cannabis plant; however, CBGA is at the top of the cascade reaction that produces the three 
major cannabinoids: THC, $\mathrm{CBD}$, and $\mathrm{CBC}$. In small proportions, CBGA may convert to CBG, but most of the CBGA produced in the Cannabis plant converts into either THC or CBD [106].

Cannabigerivarin (CBGV) and cannabigerivarinic acid (CBGVA) were isolated by Shoyama et al. between 1975 and 1977: CBGV from the benzene extract of Cannabis, and CBGVA from an extract of dried leaves of Thai Cannabis $[107,108]$.

Cascio et al. found that $\mathrm{CBG}$ binds the $\mathrm{CB} 1$ receptor from mouse brain membranes with $\mathrm{Ki}=381 \mathrm{nM}$, and the $\mathrm{CB} 2$ receptor from $\mathrm{CHO}$ cells expressing the human receptor with $\mathrm{Ki}=2.6 \mu \mathrm{M}$ [86]. In 2014, Rosenthaler et al. obtained Ki values of $897 \mathrm{nM}$ for CB1 and $153 \mathrm{nM}$ for CB2 in competition assays [69]. Additionally, CBG did not produce psychotropic effects in the in vivo tests, but it did affect endocannabinoid function indirectly by inhibiting anandamide uptake, contributing to increasing the levels of anandamide [76].

In a 2020 study, it was demonstrated that CBGA has a very low affinity for both CB1R and CB2R using [3H]-CP-55940 as a ligand, and thus the compound lacks pharmacological effects due to $\mathrm{CB}$ receptor modulation, while $\mathrm{CBGV}$ was the compound with greater affinity. From this class of phytocannabinoids, CBGV remains the only one with questionable behavior regarding cannabinoid receptors because, in the same study, the authors concluded that CBGV has a complex behavior, acting as a potent agonist, through Gi and MAPK pathway activation, studied in vitro, but with the observation that, in vivo, CBGV acts as an inverse agonist of cannabinoid receptors [67].

Because these compounds showed only a marginal affinity for $\mathrm{CB}$ receptors, they were not taken into account in studies until recently, but it seems that they have a lot of other pharmacological effects with possible applications in the treatment of neurodegenerative diseases, inflammatory disease, cancer, anxiety, and depression [72], as well as infectious diseases, metabolic disorders, and psoriasis $[64,109,110]$.

It was found that this class of compounds along with derivative compounds presents many different actions such as neuromodulatory, neuroprotective, anti-inflammatory, analgesic, anxiolytic, antidepressant, and antibacterial activity, or that they can be used to treat cancer, psoriasis, metabolic diseases such as diabetes and their complications, anorexia, or cancer-induced cachexia by mechanisms that do not involve CB receptors [72,74,86,111,112].

Transient receptor potential ankyrin 1 (TRPA1) is a good target for the discovery of novel medicines to treat pain because it has a primary role in nociceptive transduction and neurogenic inflammation, contributes to noxious cold sensation, and plays a role in neuropathic and inflammatory pain [113]. TRPA1 is activated by CBG with an EC50 value of $3.4 \pm 1.0 \mu \mathrm{M}(0.6 \pm 0.1)$, but it was found that through cyclization, the activity on this receptor is increased, and the cyclized analog of CBG could be considered for future studies as an analgesic and anti-inflammatory agent [75].

Transient Receptor Potential Melastatin-8 (TRPM8) is a non-selective cation channel activated by cold temperature and by cooling agents, and a neuronal sensor that plays a role in cold and mechanical allodynia associated with neuropathic pain secondary to trauma. It was proved that this channel is involved in pain perception, and that TRPM8 activation or deactivation can modulate analgesia [114]. De Petrocellis demonstrated in his paper that CBG is the second most efficient TRPM8 antagonist, and he found that a "CBG-free" extract from the Cannabis plant (with the exact quantity of CBG that was extracted from the plant) was inactive per se, but when added to pure CBG, the activity of the CBG-enriched extract was significantly increased, and it was more efficient in antagonizing TRPM8 than pure CBG. Thus, he suggested that there might be a synergistic effect between pure CBG and some of the components of its corresponding Cannabis extract [72].

Transient receptor potential vanilloid-3 (TRPV3) and transient receptor potential vanilloid-type 4 (TRPV4) are indirectly involved in gastrointestinal inflammation from inflammatory bowel diseases because they function as sensors of harmless and nonharmless chemical or physical stimuli [115]. It was demonstrated on in vitro models of overexpressed TRPV3 channels (against carvacrol) and overexpressed TRPV4 channels (against $4 \alpha$-phorbol-12,13-didecanoate( $4 \alpha$-PDD)) that CBG produced a significant TRPV3 
and TRPV4 desensitization as a result of their activation, which was associated with an anti-inflammatory effect [76]. In another in vivo model of murine colitis produced by intracolonic administration of dinitrobenzene sulphonic acid (DNBS), CBG had an antiinflammatory effect associated with the downregulation of cytokines and inducible nitric oxide synthase expression (iNOS) levels [77].

In a study from 2012, the same author measured the activity of CBGA and CBGV on in vitro models of overexpressed TRPV3 channels (against carvacrol) and overexpressed TRPV4 channels (against $4 \alpha$-phorbol-12,13-didecanoate( $4 \alpha-\mathrm{PDD})$ ). The results suggested that these two compounds desensitize TRPV3 and TRPV4 channels at lower doses than those at which they stimulate these channels. These findings have led to the conclusion that these compounds are good candidates for studies on in vivo models of conditions involving overexpression of TRPV3 and TRPV4 channels, which involve pain and inflammation in inflammatory bowel disease (IBD) [76].

TRPV1 is activated by heat, protons, and proinflammatory cytokines and is associated with pain and inflammation. The results of several studies suggest the potential of TRPV1 agonists, antagonists, and positive allosteric modulators in the treatment of pain [104-106]. It seems that CBGA can stimulate human TRPV1 sufficiently in order to be a potent candidate for future studies on TRPV1-modulating effects $(E C 50=1.0-2.0 \mathrm{mM})$ to treat pain and inflammation [72].

In a 2011 study, CBG and CBGA showed inhibition of more than $30 \%$ of cyclooxygenase1 (COX-1) and cyclooxygenase-1 (COX-2) in a concentration-dependent manner, thus having enhanced anti-inflammatory effects [62]. CBG has also been found to have antiinflammatory action by interfering with the prostaglandin E2 (PGE2) synthesis pathways at various levels: by inhibiting the enzyme cytosolic phospholipase A2 (PLA2), which catalyzes the production of arachidonic acid from membrane phospholipids, or by inhibiting monoacylglycerol lipase (MAGL), which catalyzes the production of arachidonic acid from 2-arachidoylglycerol [25].

Animal studies (mice) have shown that CBG has antinociceptive and anti-inflammatory effects on several acute pain models such as those induced by using intraperitoneally administered formalin and carrageenan. Both models are mediated by $\alpha 2$-adrenoceptor because they are blocked by yohimbine, an $\alpha 2$-adrenoceptor antagonist [25].

In a computational model of $\alpha 2 \mathrm{~A}, \alpha 2 \mathrm{~B}$, and $\alpha 2 \mathrm{C}$ isoforms of murine and human adrenoceptors, CBG affinity for the receptor appeared higher than that of the $\alpha 2$-adrenergic receptor agonist clonidine. This affinity of CBG seems to be associated with sedation and analgesia and needs future research [116].

CBG exhibits the best growth inhibition against human oral epithelioid carcinoma cell lines and fibroblasts and has antiproliferative action in mouse skin melanoma cells [117,118].

It was also shown that TRPM8 expression strongly increases in prostatic cancer, and in neuroendocrine tumor cells from pancreatic cancer and colon cancer. CBG seems to be a potent TRPM8 antagonist (IC50 $=0.16 \pm 0.02)$, which suggests it may have a therapeutic effect in these types of cancers [72].

In another study published in 2014, it was shown that CBG inhibits the growth of colorectal cancer cells primarily through a pro-apoptotic mechanism and blocks colon carcinogenesis in vivo. This effect of CBG is associated with reactive oxygen species overproduction, and the authors suggested that CBG can be a promising curative and preventive pharmacological agent for colorectal cancer [111].

Transient receptor potential cation channel subfamily V member 1 (TRPV1), also named "capsaicin receptor", was recently reported to be aberrantly expressed in many tumor types such as breast cancer, skin tumors, or colon cancer. It was found in several studies that its activation by capsaicin was associated with antiproliferative effects. That is why the TRPV1 channel offers new treatment possibilities for cancer [119]. In a study of the effects of cannabinoids on ionotropic TRP channels conducted by De Petrocellis in 2011, it was demonstrated that CBGA stimulated human TRPV1 enough to be a potent candidate for future studies on agents that modulate TRPV1 [72]. 
CBGV is the most important antagonist of TRPV2 $(\mathrm{EC} 50=1.7 \mu \mathrm{M})$, enough to be considered as a potential pharmacological agent to treat cancer because the overexpression of TRPV2 has been linked to several cancer types and cell lines such as urothelial cancers, prostate cancer, breast cancer, esophageal squamous cell carcinoma, and benign hepatoma, and in hepato-carcinomas and hematological malignancies, such as myeloma or acute myeloid leukemia [72]. TRPV2 channels control multiple processes involved in cancer progression by modulating survival, cell proliferation, angiogenesis, migration, and invasion in different cancer types. Clinical data suggest there might be a direct relationship between altered TRPV2 expression and a negative prognosis [81].

A recently published article concluded that CBGA is a good candidate for colorectal cancer treatment, with increased toxic activity on colorectal cancer cells and reduced activity on normal colon cell lines. In the same study, it was found that CBGA acts synergistically with THCA against neoplastic cells, but with a CBGA fraction that is greater than the THCA fraction. The cytotoxic activity of CBGA and THCA + CBGA most often led to cell cycle arrest and apoptotic cell death for cancer cells. CBGA, THCA, and CBGA + THCA are also active on adenomatous polyps, suggesting another possible therapeutic value [120].

TRPV1 is involved in the modulation of anxiety and may have implications in the treatment of depression [121]. TRPV1 may affect the locomotor activity and plays a role in thermosensation as it can be activated by noxious heat $\left(>42{ }^{\circ} \mathrm{C}\right)[122,123]$. Due to all these findings and considering De Petrocellis's studies on the modulatory action of CBGA on TRPV1, we can assume that CBGA could be a potent candidate for future studies on TRPV1-modulating effects to treat the neurological disorders in which these channels are involved, such as anxiety or depression [72,76].

In an experiment performed on mouse brain membranes, it was proved that CBG can activate $\alpha 2$-adrenoreceptors and block 5-HT1A receptors, antagonizing the 5-HT1A receptor agonist $\mathrm{R}-(+)-8-h y d r o x y-2-($ di-n-propylamino) tetralin. The authors concluded that CBG has the ability to inhibit noradrenaline uptake in the [35S] GTP $\gamma S$ binding assay, the brain needs further investigation, and more in vivo experiments are required to verify that the in vitro dose is enough to also be effective in vivo without adverse effects [86].

In an in vivo model of multiple sclerosis produced with TMEV (Thaler's murine encephalomyelitis virus), CBG and CBG-quinone showed anti-inflammatory and neuroprotective effects through the inhibition of IL-1 $\beta$ and IL-6 cytokines, and downregulation of PGE2 synthesis. CBG and CBG-quinone inhibited the microglia inflammatory response, protected neurons from toxic insults in vitro, and restored motor function impairment [124].

Using an in vivo model of Huntington's disease (HD), created using nitopropionic acid (3-NPA), CBG efficacy was tested using a dose of $10 \mathrm{mg} / \mathrm{kg} /$ day administered i.p. and was shown to have neuroprotective effects by downregulating the proinflammatory markers COX-2, iNOS, IL-6, and TNF- $\alpha$, by preventing neuronal degradation, downregulating disease-associated genes $S g K L$ and $C D 44$, and normalizing specific protein-1 levels. Clinically, specific symptoms such as dystonia and tightening of the hind limbs were visibly improved, and locomotor activity was enhanced [125].

In an in vitro model of neuroinflammation on NSC-34 motor neurons, pretreatment with CBG $(7.5 \mu \mathrm{M})$ improved viability in treated cells through the inhibition of cell apoptosis, a reduction in IL- $1 \beta, \mathrm{TNF}-\alpha, \mathrm{IFN}-\gamma$, and PPAR- $\gamma$ proinflammatory protein levels, a reduction in oxidative stress, and upregulation of Nrf-2 levels [74].

CBG blocked cell death, reduced oxidative damage, and prevented neurons from accumulating toxic $\beta$-amyloid protein, in an in vitro Alzheimer's disease model [126].

In an in vitro study on the effect of CBGA and CBG on the aldose reductase (ALR2) enzyme, it was found that both drugs showed statistically significant ALR2 inhibitory activity by being able to interact with the major active site of the enzyme. Considering that ALR2 is a key enzyme involved in diabetic complications, the results obtained in this study may have some relevance in medicine to prevent or treat possible diabetic complications [79]. 
In a 2019 in silico study, a computer simulation was developed in order to assess CBGA's role in activating peroxisome proliferator-activated receptors (PPARs) that regulate metabolism. Three phytocannabinoids, namely, CBGA, CBDA, and CBG, were thus identified as being PPAR $\alpha / \gamma$ dual agonists. The study established that they act as full or partial agonists on PPAR $\alpha / \gamma$ isoforms. Effects on downstream gene transcription in adipocytes and hepatocytes were also noted, further certifying their roles as functional dual agonists [80]. It is already known that peroxisome proliferator-activated receptor agonists such as rosiglitazone and pioglitazone are used to treat diabetes to improve the pathogenesis of insulin resistance and hyperglycemia; therefore, CBGA can be considered a good candidate for the treatment of diabetes complications [127].

It was found that higher doses (120 to $140 \mathrm{mg} / \mathrm{kg}$ ) of GBG induce a dose-dependent increase in food intake, increase the number of meals taken, decrease the latency until the first meal, and improve locomotor activity [128]. Another study also found that pure CBG $(120 \mathrm{mg} / \mathrm{kg})$ can attenuate weight loss induced by the chemotherapy agent cisplatin [25]. Due to these findings, CBG could be useful for the treatment of feeding disorders and weight loss in cancer anorexia-cachexia syndrome $[25,128]$.

It was found that CBG has antibacterial properties against Gram-positive bacteria, mycobacteria, and fungi [109]. Recently, the antibacterial properties of CBG were tested against various methicillin-resistant Staphylococcus aureus (S. aureus) strains of current clinical relevance, and the results were promising [110].

In a 2020 study on CBG antibacterial activity against methicillin-resistant S. aureus (MRSA), it was found that, in vitro, CBG acts through the disruption of the cytoplasmatic membrane of MRSA. Using an in vivo model of systemic MRSA infection in mice, CBG was shown to express antibacterial action comparable to vancomycin, at a non-toxic dose of $100 \mathrm{mg} / \mathrm{kg}$, suggesting that CBG could be a less toxic alternative for the treatment of methicillin-resistant Gram-negative bacteria [129].

In a study on the effects of CBG in skin conditions, CBG demonstrated inhibitory action on keratinocyte proliferation in a CB1/CB2 receptor-independent manner, being a good candidate for the treatment of psoriasis [130]. Additionally, CBG acted as a transcriptional repressor controlling cell proliferation and differentiation through a mechanism that involved increasing DNA methylation on the keratin-10 gene, making CBG a good candidate for the development of novel therapeutics for skin disease [131].

\subsubsection{Cannabidiol (CBD)-Type Compounds}

Cannabidiol (CBD) is considered to be the second phytocannabinoid in abundance after $\triangle 9$-THC, biosynthesized by the plant Cannabis sativa, with a defensive role against parasites that may affect the plant, being its main non-psychomimetic compound $[26,27,132]$. Numerous preclinical and clinical studies have reported that, due to the absence of psychoactive effects, CBD could have great potential in the treatment of symptoms characteristic of neuropsychiatric disorders (anxiety, depression, substance use disorders, dependence on various drugs, epilepsy, psychosis, Parkinson's, Alzheimer's, multiple sclerosis, Huntington's disease), migraine, inflammatory diseases, rheumatoid arthritis, etc. $[26-29,133,134]$.

The CBD acidic precursor cannabidiolic acid (CBDA) is one of the most present phytocannabinoids in European hemp [32]. Of all cannabinoid acids, CBDA seems to be the one with the weakest pharmacological activity, being studied thus far for its effects in pain, inflammation, and nausea but also for its therapeutic potential in treating breast cancer and in relieving the symptoms of Dravet syndrome $[92,94,135,136]$.

Cannabidivarin (CBDV), isolated in 1969 by Vollner et al., is a CBD homolog that has begun to attract the attention of researchers for its pharmacological profile because it has low activity at CB1 receptors, thus lacking the psychotropic effects related to CB1 receptor activity $[67,137]$. Regarding CB2 receptors, the affinity of CBDV for these receptors is still under scrutiny, the results of the latest studies being contradictory. While Zagzoong et al. reported a high affinity for these receptors measured using Chinese hamster ovary $(\mathrm{CHO})$ 
cells expressing human CB2 receptors, Navarro reported a low affinity using a heterologous system expressing human versions of $\mathrm{CB} 1$ and $\mathrm{CB} 2$ receptors. In this situation, the best way to solve this contradiction is by performing more in vivo tests on the effects of CBDV on models such as chronic and acute pain, epilepsy, or anxiety as pathologies in which the activity of CB2 receptors could be involved $[65,67]$.

CBD pharmacokinetics are complex and variable, with low oral bioavailability due to incomplete oral absorption and high hepatic clearance, but can be greatly increased (4-fold) when combined with high-fat or high-calorie meals. Due to its low bioavailability, CBD shows a high pharmacokinetic variability with consequences on clinical response. Due to its highly lipophilic nature, it has a large volume of distribution $(23-43 \mathrm{~L} / \mathrm{kg})$, is highly bound to plasma proteins ( $>94 \%$ ), and the time required to reach the maximum plasma concentration when administered as a single dose is $3-5 \mathrm{~h}$. Its plasma half-life depends on the dose and route of administration, with great variability between humans and rodents, ranging from 18 to $32 \mathrm{~h}$, making dosing difficult at this time. It is excreted via feces $[67,87]$.

The numerous effects of CBD have increased the interest in its pharmacological properties. It has a low affinity for cannabinoid receptors but can act as a negative allosteric modulator of $C B$ receptors. Although it has a low affinity for these receptors, it is nevertheless interesting that CBD may favor increases in endogenous endocannabinoid levels by indirect mechanisms. However, its actions are much more varied: for example, it intervenes in modulating the activity of some neurotransmitter transporters such as dopamine, norepinephrine, adenosine, and glutamate [84,138].

It can be an agonist of transient receptors (TRPV1), of 5-HT1A receptor, and of PPAR $\gamma$ receptor, or it can modulate the activity of numerous ion channels and various enzymes as well as modulating G55 protein-coupled receptor (GPR55) [84].

CBDV has been studied in vitro and has been shown to stimulate TRPA1, TRPV1, and TRPV2 channels in a dose-dependent manner [72,88], to act as an antagonist for TRPM8 [72] channels and GPR55 [134], and to act as an inverse agonist of GPR6 [90]. CBDV may also indirectly affect CBR signaling, by inhibiting the cellular uptake of AEA, or by inhibiting diacylglycerol-lipase- $\alpha$ (DAGL $\alpha$ ) [72]. In vivo, CBDV also acts as a partial agonist for dopamine D2-like receptors [139].

CBD, CBDA, and CBDV have been found to have numerous beneficial effects on the relief of various symptoms, especially in central nervous system disorders. CBD was tested in various neurological disorders such as depression and mood disorders, schizophrenia, Dravet syndrome (DS), Lennox-Gastaut syndrome (LGS), and Alzheimer's, and in other types of pathologies such as neuropathic pain and inflammation $[29,87,91,135,138,140,141]$. CBDV has also become a good candidate as a therapeutic agent for neurological diseases such as epilepsy and autism spectrum disorders, Rett syndrome, ischemic strokes, or inflammatory pathologies such as inflammatory bowel disease (IBD) [91,142-144].

The first preclinical study showing that $\mathrm{CBD}$ could be effective in relieving depressive symptoms was published in 2010; in a murine (mouse) model, CBD reduced the immobility time in mice undergoing a forced swimming test, the effect being similar to that produced by antidepressants such as imipramine. The authrors concluded that the effects of CBD are most likely initiated by the activation of 5-HT (1A) receptors, receptors involved in the neurobiology of depression [85].

Based on the idea that $\mathrm{CBD}$ does not bind directly to $\mathrm{CB} 1$ receptors, the antidepressant effect may be due to indirect modulation of the endocannabinoid system in the prefrontal cortex with subsequent activation of $\mathrm{CB} 1$ receptors, thus promoting 5-HT(1A) activation in cortical and limbic brain regions. Both in vivo and in vitro studies have shown that chronic CBD treatment promotes hippocampal neurogenesis and synaptogenesis by increasing anandamide signaling in the hippocampus, while endocannabinoid system signaling promotes neurogenesis via $\mathrm{CB} 1$ and $\mathrm{CB} 2$ receptors. These observations may represent evidence to support CBD as a potential drug to treat mood disorders $[26,84]$.

A recent randomized, double-blind, placebo-controlled clinical trial evaluated the acute effects of tetrahydrocannabinol, cannabidiol, and their combination on the Emotional 
Recognition Facial Affect Test which showed that inhalation of a $16 \mathrm{mg}$ single dose improved subjects' performance on this test by $60 \%$ in emotion intensity [145]. Other clinical studies have shown that a single dose of CBD $(300 / 600 \mathrm{mg} / \mathrm{kg})$ reduced anxiety in healthy volunteers during public speaking, effects that may depend on changes in brain regions involved in emotional processing [26].

In recent years, research in the field has been increasingly focused on understanding the pathophysiological mechanisms involved in drug addiction, a serious public health problem, with CBD recently being considered as a potential therapeutic approach. In this regard, a preclinical study published in 2021 investigated the possible beneficial effects of CBD on relapse symptoms after amphetamine re-exposure, drug relapse being the most difficult clinical factor to control during addiction treatment. The study was conducted on 43-day-old rats, an age that was selected as it corresponds to the adolescent period, a highly vulnerable period for the development of drug abuse conditions. CBD treatment was able to prevent amphetamine relapse behavior in rats that had previously exhibited amphetamine-conditioned place preference and modulated immunoreactivity of dopaminergic targets in the prefrontal cortex and ventral striatum, areas with major involvement in drug dependence. Amphetamine impairs dopaminergic neurotransmission by altering dopamine transport, but in contrast, this study showed that CBD was able to maintain dopamine transport levels. However, this study could not state whether CBD treatment reversed the molecular changes underlying amphetamine conditioning [27].

Other preclinical and clinical studies suggest that CBD could also be useful in treating schizophrenia, since this drug seems to exert antipsychotic effects in various animal models. Thus, CBD may restore deficiencies in prepulse inhibition (PPI) of the startle reflex. PPI is described by the response decrement that occurs when an acoustic stimulus is preceded by one below the subthreshold. In schizophrenia, this behavioral modification is proposed to reflect the impaired sensorimotor gating. Furthermore, the disruption of PPI may also be induced by compounds that facilitate the inhibition of glutamatergic or dopaminergic neurotransmissions such as N-methyl-d-aspartate (NMDA) receptor antagonist, amphetamine (AMPH), or dizocilpine (MK-801) [132]. Other studies showed that $\mathrm{CBD}$ reduced apomorphine-induced stereotypy and amphetamine- and ketamine-induced hyperlocomotion, and enhanced extracellular dopamine levels in the nucleus accumbens, with doses required for its antipsychotic action being higher compared to those used to induce anxiolytic effects [26].

Epidiolex, a prescription medicine that contains $\mathrm{CBD}$, was the first drug approved in June 2018 by the Food and Drug Administration (FDA) [84,140,146], and in 2019, it was also approved by the European Medicines Agency (EMA), in the treatment of seizures associated with Dravet syndrome (DS) and Lennox-Gastaut syndrome (LGS), as well as seizures associated with tuberous sclerosis $[26,87,147]$.

The mechanisms involved in the anticonvulsant action of CBD are still unclear but may involve antagonism of G55 protein-coupled receptor (GPR55), inhibition of adenosine reuptake, and desensitization of vanilloid type 1 receptor (TRPV1) [87].

GPR55 is currently considered an orphan receptor whose activation triggers a series of events followed by intracellular $\mathrm{Ca}^{2+}$ release with modulation of neurotransmitter release and neuronal excitability [141]. It acts as an antagonist of GPR55, reducing the frequency, severity, and duration of spontaneous seizures, which has been demonstrated and validated in a genetic mouse model of Dravet syndrome [89].

Rett syndrome (RTT) is a rare genetic neurological disorder characterized by severe impairments affecting the ability to speak, walk, eat, and even breathe easily; it is most often diagnosed in children [143]. GPR55 was found to be increased in the Rett syndrome mouse hippocampus, suggesting that GPR55 antagonists could be potential pharmacological agents for this pathology [144]. Given that CBDV proved to have antagonistic proprieties on GPR55 [148], several studies on RTT mouse models were performed in order to study the effects of CBDV on disease symptoms. After 14 days of daily administration, CBDV proved to attenuate brain alterations, restore the compromised general status, increase sociability, 
and partially restore motor coordination in treated mice [144], and after 4-9 weeks of administration, CBDV delayed the appearance of neurological defects [143].

In a preclinical study using rats with autism-like behavior, created through prenatal valproic acid exposure, CBDV proved to ameliorate behavioral abnormalities, restore hippocampal endocannabinoid signaling, and decrease neuroinflammation, indicating that CBDV could be a potential therapeutic agent for autism spectrum disorders [149].

As for vanilloid type 1 receptor desensitization, CBD can modulate the intracellular $\mathrm{Ca}^{2+}$ concentration. The effect of TRPV1 activation and inhibition on the seizure threshold is complex, and although it is mainly a TRPV1 agonist, CBD causes rapid desensitization of the channel with a role in the antiseizure activity.

In the brain, adenosine acts as an endogenous anticonvulsant by stimulating A1 and other adenosine receptors. CBD is a potent inhibitor of the equilibrative nucleoside transporter that mediates adenosine reuptake followed by an increased extracellular concentration [147].

Another CNS pathology is Alzheimer's disease, a condition mainly characterized by the formation of senile $\beta$-amyloid plaques and neurofibrillary tangles caused by hyperphosphorylation of tau proteins. In in vitro studies, CBD inhibited tau hyperphosphorylation and reduced $A \beta$ production, and in in vivo studies, it reversed cognitive impairments on a double AD transgenic mouse model (APP/PS1) [26].

The acidic form of CBD was studied for its anticonvulsant effect in a mouse model of Dravet syndrome, and it was found that CBDA exhibited significant anticonvulsant properties through a mechanism that could involve the 5-HT1A, GPR55, or TRPV1 receptors [136].

It is important to note that CBD does not only act on CNS structures. Available data suggest that CBD has a potent anti-inflammatory effect, which could make it a promising candidate for various diseases, being a modulator of the immune system, causing a decrease in proinflammatory cytokines (interleukin $1-\beta$, interleukin 6 , interferon- $\beta$ ) in lipopolysaccharide-activated microglial cells as well as interleukin 10 and 12 in murine macrophages [150].

Recent studies have shown that CBD has promising potential in chronic, neuropathic, and inflammatory pain [82]. Cannabidiol modulates chronic neuropathic pain and depression-specific behavior by activating 5-HT1A and CB1 receptors in the prefrontal cortex, a fact which has been demonstrated in animal models. A preclinical study in Wistar rats aimed to create a model of neuropathic pain induced by sciatic nerve injury. There is a close link between chronic neuropathic pain and depression, with the prelimbic division of the medial prefrontal cortex being directly involved in both conditions. The authors found that local cannabidiol administration attenuated mechanical allodynia as well as depression-like behavior. This study showed that acute systemic administration of cannabidiol increases extracellular serotonin levels through activation of 5HT1A and CB1 in the ventromedial prefrontal cortex, involved in the regulation of emotional impairment, as cannabidiol may be proposed as a potential drug with therapeutic indications for the treatment of depressive disorders associated with chronic neuropathic pain [83].

A 2021 study concluded that CBDV and CBG (discussed previously) have neuroprotective and anti-inflammatory properties on an in vitro model of ischemic stroke obtained by exposing cells to ischemic conditions through oxygen-glucose deprivation [151].

The anti-inflammatory activity of CBDV was studied previously on an IBD mouse model of DNBS- and dextran sulfate sodium (DSS)-induced colitis. It was found that the administration of CBDV (orally or intraperitoneally) reduced the specific signs of colon inflammation-neutrophil infiltration and increased colon weight and intestinal permeability [91]. In the same study, human colonic tissues from children with active ulcerative colitis were treated in vitro with $\mathrm{CBGV}$, and it was shown that this treatment produced a significant reduction in the proinflammatory cytokine levels (IL-1 $\beta$ ) [91]. 
CBDA was also reported to produce anti-inflammatory and anti-hyperalgesia effects on carrageenan-induced hyperalgesia and edema in rodent models of inflammatory pain when administrated i.p. 60 min before carrageenan [135].

CBDA was also studied for its anticancer properties, and the authors reported that this compound is a potent MDA-MB-231 breast cancer cell migration inhibitor, through a mechanism that is supposed to involve the activation of RhoA (an inhibitor of cancer cell mobility), and, at the same time, the inhibition of cAMP-dependent protein kinase A [94].

In two studies, from 2013 and 2020, researchers found that CBDA can potently suppress nausea and vomiting in rats through the activation of the serotonin $1 \mathrm{~A}$ receptor (5-HT1A) using animal models of acute lithium chloride-induced nausea [92,93].

However, CBD pharmacology is complex, affecting many different targets. It appears to bind to the same transmembrane protein site as cholesterol, interacting directly with a wide range of targets. Both cholesterol and CBD alter membrane elasticity and can specifically or non-specifically inhibit a wide range of transmembrane targets [136]. Cannabinoids such as CBD are transported to the endoplasmic reticulum by fatty acid-binding protein, the endoplasmic reticulum being the site of cholesterol homeostasis. CBD appears to alter cholesterol homeostasis by modulating the PPAR $\gamma$ receptor which lowers cholesterol levels by reducing HMG-reductase and increasing CYP7A1, but this mechanism is inconsistent with recent evidence that CBD can increase cholesterol levels [140].

As side effects, CBD can cause drowsiness/sedation, diarrhea, decreased appetite, rash, fatigue, sleep disturbances, increased liver transaminases, anemia, viral infections, and behavioral changes. Due to hepatic metabolism, it may cause drug-drug interactions in combination with drugs metabolized by the cytochrome P450 superfamily, such as warfarintype anticoagulants, direct oral anticoagulants (dabigatran), antiaggregants (clopidogrel), and various antiepileptic drugs (clobazam, topiramate, zonisamide) $[29,82,87,146]$. In a 2019 study, Andreson et al. showed that CBD-clobazam interaction could be used to improve the anticonvulsant effect of CBD, but only when an anticonvulsant dose of CBD is used, meaning a sub-anticonvulsant dose of CBD did not potentiate the effects of clobazam, despite the presence of pharmacokinetic interaction (Anderson et al., 2019). These are not the only drug interactions of $\mathrm{CBD}$, and its metabolism can be inhibited by ketoconazole (CYP3A4 inhibitor) or induced by rifampicin. Other reports suggest that CBD may increase plasma concentrations of tacrolimus and everolimus [29,82,87,146,147].

Table 3. The most important findings in preclinical studies on major cannabinoids and their related compounds.

\begin{tabular}{|c|c|c|c|c|}
\hline Class & Compound & Experimental Model & Findings & Reference \\
\hline \multirow{3}{*}{ CBG } & CBG & $\begin{array}{c}\text { Mouse model of intestinal } \\
\text { inflammation induced with the } \\
\text { intracolonic administration of } \\
\text { DNBS }\end{array}$ & $\begin{array}{l}\text { Anti-inflammatory effect associated with } \\
\text { the downregulation of inflammatory } \\
\text { cytokines interleukin- } 1 \beta \text {, interleukin-10, } \\
\text { and interferon- } \gamma \text { and reduction in iNOS } \\
\text { expression. }\end{array}$ & [77] \\
\hline & $\begin{array}{c}\text { CBG } \\
\text { CBGA } \\
\text { CBGV }\end{array}$ & $\begin{array}{l}\text { In vitro HEK-293 cells } \\
\text { stably overexpressing rat } \\
\text { recombinant } \\
\text { TRPV3 or TRPV4 }\end{array}$ & $\begin{array}{l}\text { CBGV and CBGA desensitize TRPV3 to the } \\
\text { action of carvacrol at concentrations of } \\
\text { EC50 }=0.8 \text { and } 7.4 \mu \mathrm{M} \text {. } \\
\text { CBGV, CBGA, and CBG desensitize } \\
\text { TRPV4 to the action of } \\
4 \alpha \text {-phorbol-12,13-didecanoate }(4 \alpha \text {-PDD) } \\
\text { with EC50 values of } 1.3-5.4 \mu \mathrm{M} \text {. } \\
\text { These compounds desensitize TRPV3 and } \\
\text { TRPV4 channels at lower doses than those } \\
\text { at which they stimulate these channels. }\end{array}$ & [76] \\
\hline & $\begin{array}{l}\text { CBG } \\
\text { CBGV }\end{array}$ & $\begin{array}{c}\text { HEK-293 cells stably } \\
\text { overexpressing human TRPV1 }\end{array}$ & $\begin{array}{l}\text { CBG and CBGV stimulated and } \\
\text { desensitized human TRPV1. }\end{array}$ & [72] \\
\hline
\end{tabular}


Table 3. Cont

\begin{tabular}{|c|c|c|c|c|}
\hline Class & Compound & Experimental Model & Findings & Reference \\
\hline & $\begin{array}{c}\text { CBG } \\
\text { CBGA }\end{array}$ & $\begin{array}{c}\text { COX-1 enzyme, purified from ram } \\
\text { seminal vesicles and COX-2 } \\
\text { enzyme, purified from sheep } \\
\text { placental } \\
\text { cotyledons }\end{array}$ & $\begin{array}{c}\text { Inhibition of more than } 30 \% \text { of COX }-1 \text { and } \\
292 \text { COX }-2 \text { in a concentration-dependent } \\
\text { manner. }\end{array}$ & [78] \\
\hline & CBG & $\begin{array}{l}\text { Computational model of } \alpha 2 \mathrm{~A}, \alpha 2 \mathrm{~B}, \\
\text { and } \alpha 2 \mathrm{C} \text { isoforms of murine and } \\
\text { human } 304 \text { adrenoceptors }\end{array}$ & $\begin{array}{c}\text { Affinity for the receptor appeared higher } \\
\text { than that of the } \alpha 2 \text {-adrenergic receptor } \\
\text { agonist clonidine. }\end{array}$ & [152] \\
\hline \multirow{3}{*}{ CBG } & CBG & Mouse skin melanoma cells & $\begin{array}{l}\text { Significant antitumor activity (inhibitory } \\
\text { concentration }(\mathrm{ICs} 0)=31.31 \mathrm{gg} / \mathrm{mL} \text { ) in } \\
\text { in vitro assay. }\end{array}$ & [117] \\
\hline & CBG & $\begin{array}{c}\text { Human oral epithelioid carcinoma } \\
308 \text { cell lines (KB) and NIH 3T3 } \\
\text { fibroblasts }\end{array}$ & $\begin{array}{c}\text { CBG exhibited the highest growth } \\
\text { inhibitory activity against the cancer cell } \\
\text { lines. }\end{array}$ & [118] \\
\hline & CBG & $\begin{array}{c}\text { HEK-293 encoding the rat TRPM8 } \\
\text { and overexpressing high levels of } \\
\text { TRPM8 }\end{array}$ & $\begin{array}{l}\text { Potent TRPM8 antagonist }(\mathrm{IC} 50=0.16 \pm \\
0.02) .\end{array}$ & {$[72]$} \\
\hline \multirow{3}{*}{ CBG } & $\mathrm{CBG}$ & $\begin{array}{l}\text { Two human colon adenocarcinoma } \\
\text { cell lines (Caco-2 and HCT 116, } \\
\text { ATCC); Mouse azoxymethane } \\
\text { (AOM) model of colon } \\
\text { carcinogenesis }\end{array}$ & $\begin{array}{l}\text { CBG inhibits the growth of CRC cells } \\
\text { mainly via a pro-apoptotic mechanism and } \\
\text { hinders the development and the growth of } \\
\text { colon carcinogenesis in vivo. }\end{array}$ & [111] \\
\hline & & Mouse brain membranes & $\begin{array}{c}\text { CBG activates } \alpha 2 \text {-adrenoreceptors and } \\
\text { blocks 5-HT1A receptors, antagonizing the } \\
\text { 5-HT1A receptor agonist } \\
\text { R-(+)-8-hydroxy-2-(di-n-propylamino) } \\
\text { tetralin. }\end{array}$ & [86] \\
\hline & CBG & $\begin{array}{l}\text { TMEV (Thaler's murine } \\
\text { encephalomyelitis virus)-induced } \\
\text { demyelinating disease } \\
\text { (TMEV-IDD) in SJL/J mice }\end{array}$ & $\begin{array}{l}\text { Anti-inflammatory and neuroprotective } \\
\text { effects through the inhibition of IL-1 } \beta \text { and } \\
\text { IL-6 cytokines, and downregulation of } \\
\text { PGE2 synthesis. } \\
\text { CBG and CBG-quinone inhibited the } \\
\text { microglia inflammatory response, } \\
\text { protected neurons from toxic insults. }\end{array}$ & [124] \\
\hline \multirow{5}{*}{ CBG } & CBG & $\begin{array}{l}\text { Mouse model of Huntington's } \\
\text { disease (HD), created using } \\
\text { 3-Nitropropionate i.p. repeated } \\
\text { administration }\end{array}$ & $\begin{array}{l}\text { Neuroprotective effects by downregulating } \\
\text { the proinflammatory markers COX-2, } 367 \\
\text { iNOS, IL-6, and TNF- } \alpha \text {, by preventing } \\
\text { neuronal degradation, downregulating } \\
\text { disease-associated genes SgKL and CD44, } \\
\text { and normalizing specific protein-1 levels. }\end{array}$ & [125] \\
\hline & CBG & $\begin{array}{c}\text { In vitro model of neuro } \\
\text { inflammation on NSC-34 motor } \\
\text { neurons }\end{array}$ & $\begin{array}{c}\text { Pretreatment with CBG }(7.5 \mu \mathrm{M}) \text { improved } \\
\text { viability in treated cells through the } \\
\text { inhibition of cell apoptosis, reduction in } \\
\text { IL-1 } \beta, \text { TNF- } \alpha \text {, IFN- } \gamma \text {, and PPAR- } \gamma \\
\text { proinflammatory protein levels, reduction } \\
\text { in oxidative stress, and upregulation of } \\
\text { Nrf- } 2 \text { levels. }\end{array}$ & {$[74]$} \\
\hline & CBG & $\begin{array}{l}\text { MC65 human neuron-like cell lines } \\
\text { treated to induce intra-neuronal } \\
\text { Alzheimer's disease cell alterations }\end{array}$ & $\begin{array}{l}\text { CBG blocked cell death, reduced oxidative } \\
\text { damage, and prevented neurons from } \\
\text { accumulating toxic } \beta \text {-amyloid protein. }\end{array}$ & [126] \\
\hline & CBG & Male Lister hooded rats & $\begin{array}{l}\text { Doses between } 120 \text { and } 140 \mathrm{mg} / \mathrm{kg} \text { of CBG } \\
\text { induced a dose-dependent increase in food } \\
\text { intake, increased the number of meals } \\
\text { taken, decreased the latency until the first } \\
\text { meal, and improved locomotor activity. }\end{array}$ & [128] \\
\hline & CBG & $\begin{array}{c}\text { Standard S. aureus strain } \\
\text { (ATCC 25923) and a clinical isolate } \\
\text { (XU212) } \\
\text { MRSA strain }\end{array}$ & Antibacterial properties. & {$[110]$} \\
\hline
\end{tabular}


Table 3. Cont.

\begin{tabular}{|c|c|c|c|c|}
\hline Class & Compound & Experimental Model & Findings & Reference \\
\hline & & $\begin{array}{l}\text { Methicillin-resistant S. aureus } 404 \\
\text { (MRSA) strain; } \\
\text { murine systemic infection model } \\
\text { caused by MRSA }\end{array}$ & $\begin{array}{c}\text { In vitro disruption of the cytoplasmatic } \\
\text { membrane of MRSA. } \\
\text { In vivo efficacy against MRSA. }\end{array}$ & [129] \\
\hline & CBG & $\begin{array}{l}\text { Keratinocyte proliferation assay } \\
\text { Human keratinocytes } \\
\text { (HaCaT cells) }\end{array}$ & $\begin{array}{l}\text { CBG had an inhibitory action on } \\
\text { keratinocyte proliferation in a CB1/CB2 } \\
\text { receptor-independent manner. } \\
\text { CBG acted as a transcriptional repressor } \\
\text { controlling cell proliferation and } \\
\text { differentiation through a mechanism that } \\
\text { involved increasing DNA methylation on } \\
\text { the keratin-10 gene. }\end{array}$ & {$[130]$} \\
\hline & $\begin{array}{l}\text { CBG } \\
\text { CBGA }\end{array}$ & $\begin{array}{l}\text { Human recombinant and pig } \\
\text { kidney aldose reductase }\end{array}$ & $\begin{array}{l}\text { Both compounds showed statistically } \\
\text { significant ALR2 inhibitory activity by } \\
\text { being able to interact with the major active } \\
\text { site of the enzyme. }\end{array}$ & {$[79]$} \\
\hline \multirow{3}{*}{ CBG } & CBG & $\begin{array}{l}\text { HEK-293 cells stably } \\
\text { overexpressing human TRPV1 }\end{array}$ & $\begin{array}{c}\text { Stimulates and desensitizes TRPV1 } \\
\text { channels with an of EC } 50=21.0 \pm 1.25 \text {. }\end{array}$ & {$[72]$} \\
\hline & & $\begin{array}{l}\text { Colon cancer cells and normal } \\
\text { colon cell lines }\end{array}$ & $\begin{array}{l}\text { Cytotoxic activity on colon cancer cells, but } \\
\text { reduced activity on normal colon cell lines. }\end{array}$ & [120] \\
\hline & CBGV & $\begin{array}{c}\text { HEK-293 cells encoding the rat } \\
\text { TRPV2 and expressing high levels } \\
\text { of TRPV2 }\end{array}$ & $\begin{array}{l}\text { Antagonizes TRPV2 channels with an EC50 } \\
=1.7 \mu \mathrm{M} .\end{array}$ & {$[72]$} \\
\hline \multirow{5}{*}{ CBD } & CBD & $\begin{array}{l}\text { Murine (mouse) model of } \\
\text { depression }\end{array}$ & $\begin{array}{l}\text { CBD reduced immobility time in mice } \\
\text { undergoing forced swimming test, the } \\
\text { effect being similar to that produced by } \\
\text { antidepressants such as imipramine. }\end{array}$ & {$[85]$} \\
\hline & CBD & $\begin{array}{l}\text { Mouse model of autism spectrum } \\
\text { disorders }\end{array}$ & $\begin{array}{c}\text { 10-20 mg/kg acute administration of CBD } \\
\text { determined an improvement in social } \\
\text { behavior. }\end{array}$ & {$[89]$} \\
\hline & CBD & Alzheimer's disease mouse model & $\begin{array}{l}20 \mathrm{mg} / \mathrm{kg} \text { sub-chronic administration of } \\
\mathrm{CBD} \text { reversed cognitive deficits in object } \\
\text { recognition memory and social recognition } \\
\text { memory. }\end{array}$ & {$[153]$} \\
\hline & CBD & $\begin{array}{l}\text { PTSD determined by yohimbine } \\
\mathrm{HCl} \text { (Tocris) administration in } \\
\text { Wistar rats }\end{array}$ & $\begin{array}{l}10 \mathrm{mg} / \mathrm{kg} \text { acute administration came with } \\
\text { therapeutic benefits for post-traumatic } \\
\text { stress disorder symptoms. }\end{array}$ & {$[154]$} \\
\hline & CBD & $\begin{array}{l}\text { Human breast cancer cell lines } \\
\text { MDA-MB231 and MDA-MB436 }\end{array}$ & $\begin{array}{l}\text { Significantly decreased Id-1 expression in } \\
\text { metastatic breast cancer cells, leading to the } \\
\text { downregulation of tumor aggressiveness. }\end{array}$ & {$[155]$} \\
\hline \multirow{3}{*}{ CBD } & CBDV & $\begin{array}{c}\text { HEK-293 cells stably } \\
\text { overexpressing human TRPV1 } \\
\text { HEK-293 cells encoding the rat } \\
\text { TRPV2 and expressing high levels } \\
\text { of TRPV2 } \\
\text { HEK-293 cells over- } \\
\text { expressingTRPA1 } \\
\text { HEK-293 encoding the rat TRPM8 } \\
\text { and overexpressing high levels of } \\
\text { TRPM8 }\end{array}$ & $\begin{array}{l}\text { Stimulates TRPV1 channels. } \\
\text { Stimulates TRPV2 channels. } \\
\text { Stimulates TRPA1 channels. } \\
\text { Antagonizes TRPM8 channels. }\end{array}$ & {$[72]$} \\
\hline & & hGPR55-HEK293 cells & Antagonizes GPR55 channels. & {$[148]$} \\
\hline & CBD & $\begin{array}{l}\text { 43-day-old rats received d,l-AMPH } \\
\text { (4 mg/kg, i.p.) or vehicle in the } \\
\text { conditioned place preference }(\mathrm{CPP}) \\
\text { paradigm ( } 8 \text { days), when each } \\
\text { experimental group was } \\
\text { re-assigned to receive CBD at two } \\
\text { different doses ( } 5 \text { or } 10 \mathrm{mg} / \mathrm{kg}, \mathrm{i} . \mathrm{p}) \\
\text { or control, for } 5 \text { days }\end{array}$ & $\begin{array}{l}\text { CBD treatment prevented amphetamine } \\
\text { relapse behavior in rats that had previously } \\
\text { exhibited amphetamine-conditioned place } \\
\text { preference, modulated immunoreactivity } \\
\text { of dopaminergic targets in the prefrontal } \\
\text { cortex and ventral striatum, areas with } \\
\text { major involvement in drug dependence. } \\
\text { CBD maintains dopamine transport levels. }\end{array}$ & [27] \\
\hline
\end{tabular}


Table 3. Cont.

\begin{tabular}{|c|c|c|c|c|}
\hline Class & Compound & Experimental Model & Findings & Reference \\
\hline & CBD & $\begin{array}{l}\text { Mouse genetic model of Dravet } \\
\text { syndrome (DS) }\end{array}$ & $\begin{array}{l}\text { CBD reduced the frequency, severity, and } \\
\text { duration of spontaneous seizures through } \\
\text { the antagonization of GPR55 receptors. }\end{array}$ & [89] \\
\hline & & $\begin{array}{l}\text { Mecp2 mutant mice, a model of } \\
\text { Rett syndrome (RTT) }\end{array}$ & $\begin{array}{l}\text { CBDV rescues recognition memory deficits } \\
\text { in Mecp } 2 \text { mutant mice and delays the } \\
\text { appearance of neurological defects. }\end{array}$ & [149] \\
\hline & & $\begin{array}{c}\text { Mouse model for Rett syndrome, } \\
\text { caused by mutations in the MECP2 } \\
\text { gene }\end{array}$ & $\begin{array}{l}\text { CBDV proved to attenuate brain } \\
\text { alterations, restore the compromised } \\
\text { general status, increase sociability, and } \\
\text { partially restore motor coordination in } \\
\text { treated mice. Molecularly, CBDV has } \\
\text { antagonistic properties on GPR55. }\end{array}$ & {$[144]$} \\
\hline & CBD & $\begin{array}{l}\text { Double AD transgenic mouse } \\
\text { model (APP/PS1) }\end{array}$ & $\begin{array}{l}\text { CBD inhibited tau hyperphosphorylation } \\
\text { and reduced } A \beta \text { production. }\end{array}$ & [26] \\
\hline \multirow{9}{*}{ CBD } & CBD & $\begin{array}{l}\text { Wistar rat model of neuropathic } \\
\text { pain (Bennet and Xie's NP model } \\
(1988))\end{array}$ & $\begin{array}{l}\text { CBD modulates chronic neuropathic pain } \\
\text { and depression-specific behavior by } \\
\text { activating } 5 \text {-HT1A and CB1 receptors in } \\
\text { the prefrontal cortex. }\end{array}$ & [83] \\
\hline & CBDV & $\begin{array}{l}\text { Autism-like behavior models } \\
\text { through prenatal valproic acid } \\
\text { exposure in rats }\end{array}$ & $\begin{array}{c}\text { CBDV ameliorated behavioral } \\
\text { abnormalities, restored hippocampal } \\
\text { endocannabinoid signaling, and decreased } \\
\text { neuroinflammation. }\end{array}$ & [149] \\
\hline & CBDV & $\begin{array}{l}\text { In vitro model of ischemic stroke } \\
\text { obtained by exposing cells to } \\
\text { ischemic conditions through } \\
\text { oxygen-glucose deprivation }\end{array}$ & $\begin{array}{l}\text { CBDV has neuroprotective and } \\
\text { anti-inflammatory properties. }\end{array}$ & {$[151]$} \\
\hline & \multirow[t]{2}{*}{ CBDV } & $\begin{array}{l}\text { IBD mouse model of DNBS- and } \\
\text { DSS-induced colitis }\end{array}$ & $\begin{array}{l}\text { CBDV (orally or intraperitoneally) reduced } \\
\text { the specific signs of colon } \\
\text { inflammation-neutrophil infiltration, and } \\
\text { increased colon weight and intestinal } \\
\text { permeability. }\end{array}$ & \multirow[t]{2}{*}{ [91] } \\
\hline & & $\begin{array}{l}\text { Human colonic tissues from } \\
\text { children with active ulcerative } \\
\text { colitis }\end{array}$ & $\begin{array}{l}\text { In vitro treatment with CBGV produced a } \\
\text { significant reduction in the } \\
\text { proinflammatory cytokine levels (IL-1 } \beta) \text {. }\end{array}$ & \\
\hline & CBDA & $\begin{array}{l}\text { Mouse model of Dravet syndrome } \\
\text { (Scn1aRX/+ mice) }\end{array}$ & $\begin{array}{l}\text { CBDA exhibited significant anticonvulsant } \\
\text { properties through a mechanism that could } \\
\text { involve the 5-HT1A, GPR55, or TRPV1 } \\
\text { receptors. }\end{array}$ & [136] \\
\hline & & $\begin{array}{l}\text { Rodent models of } \\
\text { carrageenan-induced } \\
\text { inflammatory pain }\end{array}$ & $\begin{array}{l}\text { I.p. administration of CBDA at } 60 \mathrm{~min} \\
\text { before carrageenan produced } \\
\text { anti-inflammatory and anti-hyperalgesia } \\
\text { effects. }\end{array}$ & [135] \\
\hline & & $\begin{array}{l}\text { MDA-MB-231 breast cancer cell } \\
\text { model }\end{array}$ & $\begin{array}{l}\text { CBDA inhibited cell migration through a } \\
\text { mechanism that is supposed to involve the } \\
\text { activation of RhoA and through the } \\
\text { inhibition of cAMP-dependent protein } \\
\text { kinase A. }\end{array}$ & [94] \\
\hline & & $\begin{array}{l}\text { Rat models of acute lithium } \\
\text { chloride-induced nausea }\end{array}$ & $\begin{array}{l}\text { CBDA suppresses nausea and vomiting in } \\
\text { rats through the activation of the serotonin } \\
\text { 1A receptor (5-HT1A). }\end{array}$ & {$[92,93]$} \\
\hline $\mathrm{THC}$ & $\Delta 9-\mathrm{THC}$ & $\begin{array}{l}\text { Murine model of concanavalin A } \\
\text { (ConA)-induced hepatitis }\end{array}$ & $\begin{array}{l}\text { Intraperitoneal administration of THC } \\
\text { inhibited hepatitis by significant decrease } \\
\text { in liver enzymes and reduced liver tissue } \\
\text { injury. THC treatment significantly } \\
\text { suppressed inflammatory cytokines in } \\
\text { ConA-induced hepatitis. }\end{array}$ & [156] \\
\hline
\end{tabular}


Table 3. Cont.

\begin{tabular}{|c|c|c|c|c|}
\hline Class & Compound & Experimental Model & Findings & Reference \\
\hline & $\triangle 9-\mathrm{THC}$ & Splenocytes of C57BL/6 mice & $\begin{array}{l}\text { In vitro THC treatment significantly } \\
\text { reduced proliferative response to mitogens, } \\
\text { including anti-CD3 monoclonal antibodies } \\
\text { (mAbs), concanavalin A (Con A), and } \\
\text { lipopolysaccharide (LPS). }\end{array}$ & {$[157]$} \\
\hline & $\Delta 9-\mathrm{THC}$ & Sprague Dawley male rats & $\begin{array}{c}\Delta 9 \text {-THC therapy inhibited } \\
\text { acetylcholinesterase, reduced amyloid- } \beta \\
\text { levels and hippocampal neurogenesis, and } \\
\text { induced brain-derived neurotrophic factor } \\
\text { release through mixed CB1 and CB2 } \\
\text { modulation. }\end{array}$ & {$[9,117]$} \\
\hline & $\triangle 9-\mathrm{THC}$ & $\begin{array}{l}\text { Genes encoding human, mouse, } \\
\text { and rat TRPV2 }\end{array}$ & $\triangle 9-\mathrm{THC}$ is a potent TRPV2 agonist. & {$[101]$} \\
\hline & $\Delta 8-\mathrm{THC}$ & Water-deprived albino rats & $\begin{array}{l}\text { Groups treated with } 5.0 \text { and } 10.0 \mathrm{mg} / \mathrm{kg} \text { of } \\
\Delta 8 \text {-THC reduced intake of food at } 1 \text { day } \\
\text { post-injection. }\end{array}$ & [158] \\
\hline & THCV & $\begin{array}{l}\text { Rat recombinant TRPV3- and } \\
\text { TRPV4-expressing HEK-293 cells }\end{array}$ & $\begin{array}{c}\text { Stimulates TRPV3 with high efficacy } \\
(50-70 \% \text { of the effect of ionomycin) and } \\
\text { potency (EC50 }=3.7 \mu \mathrm{M}) \text { and TRPV4 with } \\
\text { moderate-high efficacy (30-60\% of the } \\
\text { effect of ionomycin) and potency (EC50 = } \\
0.9-6.4 \mu \mathrm{M})[76] .\end{array}$ & {$[76]$} \\
\hline & $\triangle 9$-THCA & $\begin{array}{l}\text { HEK-293T, Neuro-2a (N2a), } \\
\text { STHdh Q7/Q7, and STHdh } \\
\text { Q111/Q111 cells, which express } \\
\text { either a wild-type or a mutated } \\
\text { form of the huntingtin protein }\end{array}$ & $\begin{array}{l}\Delta 9 \text {-THCA activated PPAR } \gamma \text { and increased } \\
\text { mitochondrial mass in neuroblastoma N2a } \\
\text { cells and prevented cytotoxicity induced by } \\
\text { serum deprivation in STHdh Q111/Q111 } \\
\text { cells and by mutHtt-q94 in N2a cells. } \\
\Delta 9 \text {-THCA showed potent neuroprotective } \\
\text { activity, worth } \\
\text { consideration for the treatment of } \\
\text { Huntington's disease and possibly other } \\
\text { neurodegenerative and neuroinflammatory } \\
\text { diseases. }\end{array}$ & [104] \\
\hline & $\Delta 9-\mathrm{THCA}-\mathrm{A}$ & $\begin{array}{l}\text { Mouse model of HFD significantly } \\
\text { induced obesity }\end{array}$ & $\begin{array}{l}\text { Administration of } \Delta 9-\mathrm{THCA}-\mathrm{A} \text { reduced fat } \\
\text { mass and body weight gain, markedly } \\
\text { ameliorating glucose intolerance and } \\
\text { insulin resistance, and largely preventing } \\
\text { liver steatosis, adipogenesis, and } \\
\text { macrophage infiltration in fat tissues. }\end{array}$ & {$[159]$} \\
\hline
\end{tabular}

CBG, cannabigerol; CB1, cannabinoid receptor 1; CB2, cannabinoid receptor 1; TRPM8, Transient Receptor Potential Melastatin-8; TRPV1, vanilloid receptor $1 ; \alpha 2$-Adrenoceptor, alpha-2-Adrenoceptor; IL-1 $\beta$, interleukin-1 $\beta$; TNF- $\alpha$, tumor necrosis factor alpha; IFN- $\gamma$, interferon gamma; PPAR- $\gamma$, peroxisome proliferator-activated receptor gamma; Nrf-2 levels, nuclear factor E2-related factor 2; TRPA1, transient receptor potential ankyrin 1; TRPV3, transient receptor potential vanilloid-3; TRPV4, transient receptor potential vanilloid-type 4; iNOS expression, inducible nitric oxide synthase expression; CBGV, cannabigerovarin; CBGA, cannabigerolic acid; CBD, cannabidiol; CBDV, cannabidivarin; CBDA, cannabidiolic acid; COX-1, COX-2, Cyclooxygenase-1, Cyclooxygenase-2; SOD, superoxide dismutase; PLA2, Phospholipase A2; MAGL, monoacylglycerol lipase; PPAR $\alpha / \gamma$, peroxisome proliferator-activated receptors $\alpha / \gamma ;$ GPR55, G protein-coupled receptor 55; CBDV, cannabidivarin; TRPV2, transient receptor potential vanilloid 2; GPR6, G Protein-Coupled Receptor 6; DAGL $\alpha$, diacylglycerol lipase-alpha; AEA, N-arachidonoylethanolamine (anandamide); 5HT1A, 5-hydroxytryptamine receptor 1A; cAMP protein kinase A, cyclic adenosine monophosphate protein kinase A; THC, tetrahydrocannabinol; $\triangle 9$-THC, $\triangle 9$-trans-tetrahydrocannabinol; MDSCs, myeloid-derived suppressor cells; AchE, acetylcholinesterase; $\triangle 8$-THC, $\Delta 8$-trans-tetrahydrocannabinol; THCA-A, tetrahydrocannabinolic acid; IBD, inflammatory bowel disease; ConA, concanavalin A; mAbs, monoclonal antibodies; LPS, lipopolysaccharide; i.p., intraperitoneal; DNBS, dinitrobenzene sulphonic acid; DSS, dextran sulfate sodium; AD, Alzheimer's disease. 
Table 4. The most important findings in clinical studies on major cannabinoids and their related compounds.

\begin{tabular}{|c|c|c|c|c|}
\hline Class & Compounds & Clinical Study & Results & Reference \\
\hline $\begin{array}{l}\text { CBD } \\
\text { THC }\end{array}$ & $\begin{array}{c}\text { CBD } \\
\text { THC } \\
\mathrm{THC}+\mathrm{CBD}\end{array}$ & $\begin{array}{l}\text { A 4-way, double-blind, } \\
\text { placebo-controlled crossover design } \\
\text { study in cannabis users. } \\
48 \text { volunteers, } \\
\text { CBD }(16 \mathrm{mg}), \\
\text { THC }(8 \mathrm{mg}), \\
\text { THC + CBD }(8 \mathrm{mg}+16 \mathrm{mg}) \text {, and } \\
\text { placebo, by } \\
\text { inhalation. }\end{array}$ & $\begin{array}{l}\text { CBD improved emotional facial } \\
\text { affect recognition at } 60 \% \\
\text { emotional intensity. } \\
\text { THC was detrimental to the } \\
\text { recognition of ambiguous faces of } \\
40 \% \text { intensity. } \\
\text { THC alone and combined } \\
\text { THC+CBD equally increased } \\
\text { feelings of being "stoned". }\end{array}$ & [145] \\
\hline \multirow[t]{3}{*}{ CBD } & CBD & $\begin{array}{l}\text { Double-blind, placebo-controlled } \\
\text { trial. } \\
120 \text { children and young adults with } \\
\text { the Dravet syndrome and } \\
\text { drug-resistant seizures, } \\
\text { CBD oral solution, } 20 \mathrm{mg} / \mathrm{kg} \text { of } \\
\text { body weight/day or placebo, in } \\
\text { addition to standard antiepileptic } \\
\text { treatment. } \\
\\
\text { Double-blind, randomized clinical } \\
\text { trial in } 199 \text { children with Dravet } \\
\text { syndrome on cannabidiol (10 or } \\
20 \mathrm{mg} / \mathrm{kg} / \mathrm{d}) \text { or matched placebo } \\
\text { for } 14 \text { weeks. }\end{array}$ & $\begin{array}{l}\text { The median frequency of } \\
\text { convulsive seizures per month } \\
\text { decreased from } 12.4 \text { to } 5.9 \text { with } \\
\text { cannabidiol, as compared with a } \\
\text { decrease from } 14.9 \text { to } 14.1 \text { with } \\
\text { placebo. The percentage of } \\
\text { patients who had at least a } 50 \% \\
\text { reduction in convulsive seizure } \\
\text { frequency was } 43 \% \text { with } \\
\text { cannabidiol and } 27 \% \text { with placebo. } \\
\text { Convulsive seizure frequency } \\
\text { compared with baseline was } \\
\text { reduced by } 48.7 \% \text { in the } \\
10 \text { mg/kg/d cannabidiol group } \\
\text { and } 45.7 \% \text { in the } 20 \mathrm{mg} / \mathrm{kg} / \mathrm{d} \\
\text { cannabidiol group vs. } 26.9 \% \text { in the } \\
\text { placebo group. }\end{array}$ & [161] \\
\hline & CBD & $\begin{array}{l}\text { Double-blind, placebo-controlled } \\
\text { trial conducted at } 30 \text { clinical centers; } \\
\text { we randomly assigned patients with } \\
\text { Lennox-Gastaut syndrome. } \\
225 \text { patients were enrolled; } \\
76 \text { patients were assigned to the } \\
20 \text { mg cannabidiol group, } 73 \text { to the } \\
10 \text { mg cannabidiol group, and } 76 \text { to } \\
\text { the placebo group. } \\
\text { Double-blind, placebo-controlled, } \\
\text { randomized crossover trial in } 39 \\
\text { healthy young subjects. A single } \\
\text { dose of cannabidiol e-liquid (0.25 } \\
\text { mL, } 5 \% \text { cannabidiol, } 12.5 \text { mg } \\
\text { cannabidiol) and once placebo for } \\
\text { vaping after learning } 15 \text { unrelated } \\
\text { nouns. }\end{array}$ & $\begin{array}{l}\text { The median percent reduction } \\
\text { from baseline in drop seizure } \\
\text { frequency during the treatment } \\
\text { period was } 41.9 \% \text { in the } 20 \mathrm{mg} \\
\text { cannabidiol group, } 37.2 \% \text { in the } \\
10 \mathrm{mg} \text { cannabidiol group, and } \\
17.2 \% \text { in the placebo group. }\end{array}$ & [162] \\
\hline & CBDV & $\begin{array}{l}\text { Case-control, placebo-controlled, } \\
\text { randomized, double-blind, } \\
\text { repeated-measures, crossover study } \\
\text { on } 34 \text { subjects with autism spectrum } \\
\text { disorder. }\end{array}$ & $\begin{array}{l}\text { CBDV shifts subcortical levels of } \\
\text { the brain's primary excitatory } \\
\text { metabolite glutamate both in the } \\
\text { neurotypical and autistic brain; } \\
\text { however, there may be significant } \\
\text { response variability in ASD. }\end{array}$ & [142] \\
\hline
\end{tabular}

\subsubsection{Tetrahydrocannabinol (THC)-Type Compounds}

Tetrahydrocannabinol or THC, as it is abbreviated, is the main psychoactive element of Cannabis and one of the 125 recognized cannabinoids in the plant Cannabis sativa. The term THC generally refers to the delta-9-THC isomer with the chemical name $\Delta 9$ tetrahydrocannabinol $(\triangle 9$-THC) isolated from a hexane extract of hashish in 1964 by Goani and Mecholum. Other than $\triangle 9$-THC, tetrahydrocannabivarin (THCV, isolated in 1971, from 
a Cannabis tincture of Pakistani origin), $\Delta 9$-tetrahydrocannabinolic acid A ( $\triangle 9$-THCA-A, isolated in 1967), and $\Delta 8$-trans-tetrahydrocannabinol $(\Delta-8-\mathrm{THC}$, isolated in 1966 , from the flowers and leaves of a plant grown in Maryland) are major cannabinoids also identified in Cannabis sativa [117].

In healthy people, $\Delta 9-\mathrm{THC}$ can cause acute psychotic reactions, together with a temporary decline in both cognitive function [9] and psychomotor control [164]. In patients with schizophrenia, $\triangle 9$-THC may intensify memory impairments, psychotic symptoms, and anxiety [150]; additionally, several studies have indicated a relationship between systematic Cannabis use and an increased risk of developing this condition [149]. Currently, there is growing preclinical evidence that $\triangle 9$-THC can suppress inflammation by activating CB2 or CB1/CB2 through multiple pathways, including: shifting the balance of human $\mathrm{T}$ helper 1 (Th1)/T helper 2 (Th2) cells [95], T reg differentiation [140], myeloid-derived suppressor cell induction (MDSC) [151], generation of apoptosis in dendritic and activated T cells [156,157], or induction of immunosuppressive MDSCs and T regs [165]. In Alzheimer's disease, evidence suggests that $\triangle 9$-THC therapy may inhibit acetylcholinesterase [166], reduce amyloid- $\beta$ levels [99] and hippocampal neurogenesis [100], and induce brain-derived neurotrophic factor release through mixed CB1 and CB2 modulation [96,167]. dditionally, in clinical and preclinical studies, $\triangle 9$-THC has a series of essential therapeutic benefits, such as analgesia, appetite stimulation, and antiglaucoma and antiemetic effects facilitated by both CB1 and/or CB2 activation $[97,168]$. However, the therapeutic use of $\triangle 9-T H C$ is restricted by its psychoactivity and potential for inducing tolerance and dependence. The neural basis for these divergent effects of $\triangle 9$-THC on cognitive function and psychiatric symptoms is unclear. Recent data from in vivo and in vitro studies suggest that $\Delta 9$-THC may have opposite effects than those mentioned above on cerebral CB1 receptors mediated by a partial agonism [8]. Moreover, $\triangle 9$-THC is also characterized as a partial agonist of CB2 [169,170]. As a characteristic partial agonist, $\triangle 9$-THC has a combined agonist-antagonist effect which is likely dependent on receptor expression, cells, and the simultaneous presence of endocannabinoids or other agonists [171]. The affinity of $\Delta-9-\mathrm{THC}$ for CB1 and CB2 receptors $(\mathrm{KiCB} 1=5.05 \mathrm{nM}, \mathrm{KiCB} 2=3.13 \mathrm{nM}$ [170]; KiCB1 = $35.3 \mathrm{nM}, \mathrm{KiCB} 2=3.9 \mathrm{nM}$ [172]; $\mathrm{KiCB} 1=39.5$ nM, KiCB2 = 40 nM [173]; KiCB1 = 21 nM, KiCB2 = 36.4 nM [174]; KiCB1 = $36 \mathrm{nM}, \mathrm{KiCB} 2=31 \mathrm{nM}$ [175]) exceeds or matches that of the phytocannabinoids THCV $(\mathrm{KiCB} 1=75.4 \mathrm{nM}, \mathrm{KiCB} 2=62.8 ; \mathrm{KiCB} 1=22 \mathrm{nM}, \mathrm{KiCB} 2=47 \mathrm{nM}[176])$ and $\Delta-8-\mathrm{THC}$ $(\mathrm{KiCB} 1=44 \mathrm{nM}, \mathrm{KiCB} 2=44 \mathrm{nM}$ [175]; KiCB1 = 47.6 nM, KiCB2 = 39.3 nM [177] $)$.

$\triangle 8$-THC is chemically more stable than $\triangle 9$-THC and also exhibits psychoactive effects. As with $\triangle 9$-THC, it may behave as a CB1 receptor antagonist and partial CB2 agonist [175], exhibiting similar properties in in vitro and in vivo studies: behaving as a conjugate for some fatty acids, reducing the signs of inflammation and inflammatory pain in mice, or showing inhibitory dose-dependent effects on water intake with implications for behavioral studies [178].

The lack of cannabimimetic effects has made THCA-A a more attractive compound, leading to an increase in interest in its use in the clinic [179]. Rock et al. [180] suggested that the lack of psychoactivity may be due to limited access to CB1R. Affinity and efficacy studies of THCA-A at cannabinoid receptors revealed disparate results-equal to [181] or 25-fold weaker than $\triangle 9$-THC [69], or non-affinity [182,183]. Rosenthaler et al. [69] determined a $\mathrm{Ki}$ of $23.4 \mathrm{nM}$ for THCA-A on CB1R, almost equivalent to that for $\triangle 9$-THC $(\mathrm{Ki}=35.6 \mathrm{nM})$, according to data of a $\triangle 9$-THC meta-analysis, which described a mean $\mathrm{Ki}$ of $25.1 \pm 0.39 \mathrm{nM}$ at CB1 ( $n=16$ studies) [68]. Verhoeckx et al. [182] reported a Ki of $890 \mathrm{nM}$ for THCA-A at CB1R and a $\mathrm{Ki}$ of $3.5 \mathrm{nM}$ for THC at CB1R, which is 7-fold higher than the meta-analytic mean. In line with data suggesting low affinity, THCA-A displayed low efficacy at CB1. THCA-A $(10 \mu \mathrm{M})$ may cause a small but substantial forskolin cAMP inhibition, consistent with agonist activity. Regarding CB2, in CAMP assays, THCA-A did not produce any significant effect [179].

Pharmacological data suggest that tetrahydrocannabinol-type compounds target more than canonical cannabinoid receptors [171,184]. 
$\triangle 9$-THC did not display a response at TRPV1, while several studies describe its agonistic effects at the TRPV2, TRPV3, and TRPV4 channels. Using a cell-based calcium mobilization assay and patch clamp electrophysiological evaluation, Neeper et al. [185] were able to identify $\triangle 9$-THC as a novel TRPV2 agonist. However, $\triangle 9$-THC exhibits poor selectivity and may also activate TRPA1 [101].

There are not many data on $\triangle 8$-THC activity at other targets, such as GPR18, GPR55, PPAR $\gamma$ nuclear receptors, or TRP channels. However, it is believed that this compound has a pharmacological profile similar to $\triangle 9$-THC [186].

THCV has been shown to stimulate TRPV3 with high efficacy (50-70\% of the effect of ionomycin) and potency $\left(\mathrm{EC}_{50}=3.7 \mu \mathrm{M}\right)$ and TRPV4 with moderate-high efficacy $(30-60 \%$ of the effect of ionomycin) and potency $\left(\mathrm{EC}_{50}=0.9-6.4 \mu \mathrm{M}\right)[158]$, by assessing $\left[\mathrm{Ca}^{+}\right.$] elevation in rat recombinant TRPV3- and TRPV4-expressing HEK-293 cells. THCV (potency shown as $\mathrm{EC}_{50} 1.5 \pm 0.2 \mu \mathrm{M}$ ) also stimulated human TRPV1 [76].

In vitro functional tests and docking analysis showed that THCA-A binds to and stimulates PPAR $\gamma$ by acting at both the alternative and the canonical sites of the ligandbinding domain, being at least 20-fold more potent than $\triangle 9$-THC [187]. Transcriptomic signatures, immunohistochemistry, and plasma biomarker analyses from a mouse model of high-fat diet- induced obesity treated with THCA-A has been shown to reduce fat mass and gain in body weight, significantly improve glucose intolerance and insulin resistance, and largely prevent adipogenesis, macrophage infiltration, and hepatic steatosis. Additionally, THCA-A therapy caused browning of inguinal white adipose tissue and displayed potent anti-inflammatory actions [104]. Investigating the in vivo neuroprotective activity of THCA-A in mice intoxicated with the mitochondrial toxin 3-NPA, Nadal et al. [104] showed that THCA-A therapy attenuated astrogliosis, microgliosis, and upregulation of proinflammatory markers caused by 3-NPA through a PPAR $\gamma$-dependent pathway.

The therapeutic potential of these compounds still remains largely unanswered which underlines the need for subsequent preclinical and clinical research to highlight whether these compounds can really be "a neglected pharmacological treasure trove".

\section{Structure Modulation to Obtain New Pharmacological Effects}

THC is the most explored compound of its class, being the first, in the attempt to obtain new therapeutic molecules targeting the endocannabinoid system. The group of new compounds was named "synthetic cannabinoids" and has emerged because of the need to accurately explore the endocannabinoid system and to obtain new potent therapeutic resources for pain, neurodegenerative diseases, emesis, obesity, and cancer, with minor or even absent side effects. In 1979, in an attempt to develop new analgesics, Pfizer developed several synthetic THC analogs such as CP47497 (2-[(1S, 3R) -3-hydroxycyclohexyl]5-(2-methyloctan-2-yl) phenol) and the more potent compound CP55940 (2 [(1R, 2R, 5R)5-hydroxy-2-(3-hydroxypropyl)-cyclohexyl]-5-(2-methyloctan-2-yl) phenol). These compounds have shown analgesic effects, but also marked neurological adverse effects due to the increased affinity for the CB1 receptor revealed subsequently in experimental animal studies [159].

In 1988, at the Hebrew University of Jerusalem, one of the first synthetic cannabinoids, the THC analog called HU-210, was synthesized. According to preliminary results, the drug showed strong analgesic properties, but also sleep-inducing effects, 100 times greater than those of THC [188].

In an attempt to develop high-affinity compounds that specifically target only one type of cannabinoid receptor, the first CB1 antagonist named SR141716A-Rimonabant (N-piperidino5-(4-chlorophenyl)-1-(2,4-dichlorophenyl)-4-methyl-1H-pyrazole-3-carboxamide), with a selectivity of over $1000 \times$ for CB1 over CB2, was synthesized in 1994. Of note, this drug had the ability to inhibit the psychoactive effect. Similarly, the first inverse CB2 agonist named SR144528 (N-[(1S,2S,4R)-1,3,3-trimethylbicyclo[2.2.1] heptan-2yl]-5-(4-chloro3-trimethylphenyl)-4-methyl-1-(4-methylphenyl)-1 H-pyrazole-3-carboxamide) was syn- 
thesized in 1998 [189]. Another compound with analgesic potential is the CB2 receptorselective agonist named HU-308 [173].

Experimental animal tests have shown that blocking CB1 decreases appetite and may improve the evolution of neurodegenerative and psychiatric diseases (Alzheimer's disease, schizophrenia, multiple sclerosis). On the other hand, CB1 stimulation has antiemetic, analgesic, cardioprotective, and antineoplastic effects, while CB2 stimulation has antiinflammatory and immunomodulatory properties [190].

The first attempts to structurally manipulate the structure-affinity relationship in the cannabinoid system were performed on classical cannabinoid analogs (THC), with a focus on the modification of the $\mathrm{C} 3$ side chain. Thus, it was observed that the increased length of the C3 side chain correlates directly with both the increase in affinity for CB1 and CB2 and vice versa [191]. After rigorous research on the length of the alkyl group required for binding affinity, it was established that the optimal chain length is eight carbon atoms and the minimum chain length is three carbon atoms, in order to obtain binding affinity for $\mathrm{CB}$ receptors [192]. Since then, numerous experiments have been carried out with the aim of modifying the chemical structure in order to obtain compounds with great affinity even several thousand times higher than the classic natural extracts [193].

The history of important scientific discoveries has shown that results can be interpreted and used both to make a beneficial contribution to society or to cause harm (e.g., research on the atom and atomic energy, or opioids). Therefore, research on the manipulation of the cannabinoid system is no exception in this regard.

As early as the 2000s, synthetic compounds (popularly called spice) began to be produced to be sold as psychotropic recreational drugs on the black market. Laboratory tests performed on various samples of products sold in the drug market revealed the presence of synthetic cannabinoids in various mixtures and concentrations, such as JWH-018 (an agonist of both cannabinoid receptors), and CP47497-C8 (potent agonist of CB1) [192].

The uncontrolled and unregulated use of these substances has led to significant psychiatric side effects, accidents, and highly addictive behavior, which is the reason why most of the European countries have banned them since 2009. The ban and cataloging of these compounds as high-risk drugs have not stopped the production of many other synthetic analogs and their illegal marketing, according to the European Drug Report from 2021 [194].

For these reasons, research on cannabinoids derived from THC has been heavily hampered by the stigma of high-risk banned drugs. However, there is clear evidence that cannabinoid-derived compounds can bind different types of receptors and exert their effect through mechanisms that do not necessarily involve the endocannabinoid system, which could be useful in treating several challenging conditions.

Knowing that PPAR $\gamma$ activity can be increased by natural cannabinoids such as $\Delta 9$ THC and CBD [195,196], Granja et al. conducted a study in 2012 to test the activity of CBG and its quinone derivative VCE-003 (Figure 2) on a multiple sclerosis model produced with Theiler's murine encephalomyelitis virus (TMEV). The authors demonstrated that VCE-003 is more potent than CBG on neuronal cell protection from excitotoxicity, and that VCE-003 increased PPAR $\gamma$ activity, inhibited the release of proinflammatory mediators, and decreased microglial reactivity. In the same study, the authors reported that VCE-003 has no affinity for the CB1 receptor, but it is ten times more potent in binding the CB2 receptor than CBG [115]. In 2014, the same group of researchers reported that VCE-003 had immunosuppressive and anti-inflammatory activities through the activation of PPARs and $\mathrm{CB} 2$ receptors in an in vivo model of experimental autoimmune encephalomyelitis (EAE). These two studies demonstrated that this quinone derivative of CBG is a promising therapeutic agent for the treatment of diseases with inflammatory and autoimmune components, such as multiple sclerosis or autoimmune encephalomyelitis [197]. 
<smiles>CCCCCc1cc(O)c(C/C=C(/C)CC=C(C)C)c(O)c1</smiles>

CBG<smiles>CCCCCC1=CC(=O)C(C/C=C(\C)CCC=C(C)C)=C(O)C1=O</smiles>

VCE-003<smiles>CCCCCC1=C(NCC)C(=O)C(CC=C(C)CCC=C(C)C)=C(O)C1=O</smiles>

VCE-003.2

Figure 2. Chemical structures of CBG derivatives VCE-003 and VCE-003.2.

Going further, Alonzo et al. synthetized the analog compound VCE-003.2 (Figure 3) starting from VCE-003 and tested for neuroprotective actions on an animal model of Huntington's disease induced by quinolinic acid (QA) and 3-NPA administration. VCE-003.2 administration improved motor deficits, inhibited the upregulation of proinflammatory markers, prevented medium spiny neuronal loss, and improved antioxidant defense in this in vivo model of HD [198]. In another study from 2018, the activity of VCE-003.2 was tested on an experimental model of Parkinson's disease. The authors demonstrated that this compound has no activity at $\mathrm{CB}$ receptors but has neuroprotective activity against neuronal damage caused by inflammation, through the activation of PPAR $\gamma$ receptors, and by reducing elevated levels of proinflammatory mediators such as TNF- $\alpha$, IL- $1 \beta$, COX-2, and iNOS [199].<smiles></smiles>

CBDA<smiles></smiles>

HU-580

Figure 3. Chemical structure of CBDA derivative HU-580.

The compound continued to be tested with good results on an experimental model of amyotrophic lateral sclerosis, and it was found that i.p. administration of $10 \mathrm{mg} / \mathrm{kg}$ successfully improved neuropathological deterioration and normalized IL-1 $\beta$ levels, an effect that could involve PPAR- $\gamma$ activation [200].

In 2019, Aguareles et al. and Burgas et al. tested VCE-003.2 oral administration on animal models of HD and experimental models of Parkinson's disease. The conclusion was that oral administration of VCE-003.2 protected striatal medium spiny neurons from mutant damage produced by HD, attenuated neuroinflammation, and improved motor performance [199]. In the PD model, oral administration of $20 \mathrm{mg} / \mathrm{kg}$ of VCE-003.2 protected against neuronal damage caused by inflammation [201].

Another attempt to modulate the structure of CBG was made by Annalisa Lopatriello in 2018, whose team of researchers performed an iodine-mediated cyclization of cannabigerol in an attempt to expand the pharmacological and chemical space of this major phytocannabinoid. The resulting compounds were tested for their activity on transient 
receptor potential melastatin (TRPM) receptors starting from the premise that they could have improved action on these receptors because CBG is a potent agonist of TRPMA1 and a potent antagonist of TRPM8 [72,75]. Experiments have shown that all cyclic compounds have an increased activity on TRPMA1 and a slightly improved affinity for TRPM8, which makes them better candidates for future tests as pharmacological agents in diseases with neuropathic and/or inflammatory pain [75].

Regarding cannabidiol, four authors reported results for a new derivative compound, cannabidiolic acid methyl ester (HU-580), that was tested in animal models of depression, neuropathic pain, anxiety, and nausea [202-205]. The authors found that HU-580 reduces stress-induced depression-like behavior in rats and provides antinociception in a model of peripheral neuropathic pain for male rats, with no efficacy in females [203,204]. Studied for its 5HT1A receptor-mediated activity, it was found that, in vitro, HU-580 is more potent than CBDA at enhancing 5-HT1A receptor activation and, in vivo, reduces nausea and anxiety in acute and anticipatory nausea models developed on rats [205]. In another experiment, CBD, CBDA, and HU-580 were administrated daily for one and four weeks. It seemed that the compounds maintained their effectiveness in reducing LiCl-induced vomiting and nausea in rats and shrews. Thus, these three compounds can be taken into consideration as pharmacological agents for the treatment of nausea in chronic conditions, without the risk of developing tolerance [205].

\section{Conclusions}

The multifaceted aspects of the adaptive pro-homeostatic physiological or maladaptive pathological roles of the endocannabinoid system and major phytocannabinoids—which were originally neglected-are becoming important again. Exploring the landscape of major phytocannabinoids and their derivatives beyond the cannabinoid receptors may lead to a better understanding of human physiology, which will help us to develop new and more selective compounds to better realize the therapeutic potential of cannabis in disorders with or without a multifactorial nature.

Author Contributions: Conceptualization, L.E.F., D.C.A., T.A.-S., G.D.S., and B.-I.T.; writingoriginal draft preparation, L.E.F., D.C.A., T.A.-S., G.D.S., C.V.P., and R.S.; supervision, V.B. and B.-I.T.; project administration, B.-I.T.; funding acquisition, B.-I.T. All authors have read and agreed to the published version of the manuscript.

Funding: This work was supported by a grant of the Romanian Ministry of Education and Research, CNCS-UEFISCDI, project number PN-III-P4-ID-PCE-2020-1247, within PNCDI III.

Institutional Review Board Statement: Not applicable.

Informed Consent Statement: Not applicable.

Data Availability Statement: No new data were created or analyzed in this study. Data sharing is not applicable to this article.

Conflicts of Interest: The authors declare no conflict of interest. The funders had no role in the design of the study; in the collection, analyses, or interpretation of data; in the writing of the manuscript, or in the decision to publish the results.

\section{Abbreviations}

THC, tetrahydrocannabinol; $\triangle 9$-THC, $\Delta$-9-tetrahydrocannabinol; $\triangle 8$-THC, $\Delta$-8-tetrahydrocannabinol; THCA-A, $\triangle$-9-tetrahydrocannabinolic acid; CBD, cannabidiol; CBG, cannabigerol; CBN, cannabinol; $\mathrm{CBDV}$, cannabidivarin; $\mathrm{CBC}$, cannabichromene; $\mathrm{CBND}$, cannabinodiol; $\mathrm{CBE}$, cannabielsoin; CBL, cannabicyclol; $\mathrm{CBT}$, cannabitriol; DCBF, dehydrocannabifuran; $\mathrm{CBF}$, cannabifuran; DNBS, dinitrobenzene sulphonic acid; Th1 cells, human T helper 1 cells; Th2 cells, human T helper 2 cells; CB1, cannabinoid receptor 1; CB2, cannabinoid receptor 1; TRPM8, Transient Receptor Potential Melastatin-8; TRPV1, vanilloid receptor 1; $\alpha 2$-Adrenoceptor, alpha-2-Adrenoceptor; IL-1 $\beta$, interleukin- $1 \beta$; TNF- $\alpha$, tumor necrosis factor alpha; IFN- $\gamma$, interferon gamma; PPAR- $\gamma$, peroxisome proliferator-activated receptor gamma; Nrf-2 levels, nuclear factor E2-related factor 2; TRPA1, tran- 
sient receptor potential ankyrin 1; TRPV3, transient receptor potential vanilloid-3; TRPV4, transient receptor potential vanilloid-type 4; iNOS expression, inducible nitric oxide synthase expression; COX-1, COX-2, Cyclooxygenase-1, Cyclooxygenase-2; SOD, superoxide dismutase; PLA2, Phospholipase A2; MAGL, monoacylglycerol lipase; PPAR $\alpha / \gamma$, peroxisome proliferator-activated receptors $\alpha / \gamma$; GPR55, G protein-coupled receptor 55; TRPV2, transient receptor potential vanilloid 2; GPR6, G ProteinCoupled Receptor 6; DAGL $\alpha$, diacylglycerol lipase-alpha; AEA, N-arachidonoylethanolamine (anandamide); 5HT1A, 5-hydroxytryptamine receptor 1A; cAMP protein kinase A, cyclic adenosine monophosphate protein kinase A; AchE, acetylcholinesterase; IBD, inflammatory bowel disease; ConA, concanavalin A; mAbs, monoclonal antibodies; LPS, lipopolysaccharide; i.p., intraperitoneal; DNBS, dinitrobenzene sulphonic acid; DSS, dextran sulfate sodium; AD, Alzheimer's disease.

\section{References}

1. Abel, E.L.; Emboden, W. Marihuana: The First Twelve Thousand Years. Q Rev. Biol. 1981, 56, 514.

2. Tamba, B.I.; Stanciu, G.D.; Urîtu, C.M.; Rezus, E.; Stefanescu, R.; Mihai, C.T.; Luca, A.; Rusu-zota, G.; Leon-constantin, M.M.; Cojocaru, E.; et al. Challenges and Opportunities in Preclinical Research of Synthetic Cannabinoids for Pain Therapy. Medicina 2020, 56, 24. [CrossRef] [PubMed]

3. Turgeman, I.; Bar-Sela, G. Cannabis for cancer-illusion or the tip of an iceberg: A review of the evidence for the use of Cannabis and synthetic cannabinoids in oncology. Expert Opin. Investig. Drugs 2019, 28, 285-296. [CrossRef] [PubMed]

4. Zuardi, A.W. History of cannabis as a medicine: A review. Rev. Bras. Psiquiatr. 2006, 28, 153-157. [CrossRef]

5. Farag, S.; Kayser, O. The Cannabis Plant: Botanical Aspects. In Handbook of Cannabis and Related Pathologies: Biology, Pharmacology, Diagnosis, and Treatment; Elsevier Inc.: Amsterdam, The Netherlands, 2017; pp. 3-12. ISBN 9780128008270.

6. Pertwee, R.G. Cannabinoid pharmacology: The first 66 years. Br. J. Pharmacol. 2006, 147, 163-171. [CrossRef]

7. Curran, H.V.; Freeman, T.P.; Mokrysz, C.; Lewis, D.A.; Morgan, C.J.A.; Parsons, L.H. Keep off the grass? Cannabis, cognition and addiction. Nat. Rev. Neurosci. 2016, 17, 293-306. [CrossRef]

8. ElSohly, M.A.; Radwan, M.M.; Gul, W.; Chandra, S.; Galal, A. Phytochemistry of Cannabis sativa L. In Progress in the Chemistry of Organic Natural Products; Kinghorn, A., Falk, H., Gibbons, S., Kobayashi, J., Eds.; Springer: Cham, Switzerland, 2017; Volume 103, pp. 1-36.

9. Radwan, M.M.; Chandra, S.; Gul, S.; ElSohly, M.A. Cannabinoids, phenolics, terpenes and alkaloids of cannabis. Molecules 2021, 26, 2774. [CrossRef]

10. Gaoni, Y.; Mechoulam, R. Isolation, Structure, and Partial Synthesis of an Active Constituent of Hashish. J. Am. Chem. Soc. 1964, 86, 1646-1647. [CrossRef]

11. Hively, R.L.; Mosher, W.A.; Hoffmann, F.W. Isolation of trans- $\Delta 6$-tetrahydrocannabinol from marijuana. J. Am. Chem. Soc. 1966, 88, 1832-1833. [CrossRef]

12. Adams, R.; Hunt, M. Structure of cannabidiol, a product isolated from the marihuana extract of Minnesota Wild Hemp. I. J. Am. Chem. Soc. 1940, 62, 196-200. [CrossRef]

13. Gaoni, Y.; Mechoulam, R. The structure and synthesis of cannabigerol, a new hashish constituent. Proc. Chem. Soc. 1964, 82, 82.

14. Gaoni, Y.; Mechoulam, R. Cannabichromene, a new active principle in hashish. Chem. Commun. 1966, 1, 20-21. [CrossRef]

15. Ghosh, R.; Todd, A.R.; Wilkinson, S. Cannabis indica. Part V. The synthesis of cannabinol. J. Chem. Soc. 1940, 1, 1393-1396. [CrossRef]

16. Adams, R.; Pease, D.C.; Clark, J.H. Isolation of cannabinol, cannabidiol and quebrachitol from red oil of Minnesota Wild Hemp. J. Am. Chem. Soc. 1940, 62, 2194-2196. [CrossRef]

17. Ginneken, C.; Vree, T.; Breimer, D.; Thijssen, H.; Rossum, J. Cannabinodiol, a new hashish consituent, identified by gaschromatography-mass spectrometry. In Proceedings of the International Symposium on Gas Chromatografy Mass Spectrometry, Isle Elba, Italy, 17-19 May 1972; pp. 111-129.

18. Robert, J.J.C.; Ludwig Bercht, C.A.; van Ooyen, R.; Spronck, H.J.W. Cannabinodiol: Conclusive identification and synthesis of a new cannabinoid from Cannabis sativa. Phytochemistry 1977, 16, 595-597. [CrossRef]

19. Korte, F.; Sieper, H. Zur chemischen klassifizierung von pflanzen. XXIV. Untersuchung von Haschisch-Inhaltsstoffen durch Dünnschichtchromatographie. J. Chromatogr. A 1964, 13, 90-98. [CrossRef]

20. Crombie, L.; Ponsford, R.; Shani, A.; Yagnitinsky, B.; Mechoulam, R. Hashish components. Photochemical production of cannabicyclol from cannabichromene. Tetrahedron Lett. 1968, 9, 5771-5772. [CrossRef]

21. Bercht, C.A.L.; Lousberg, R.J.J.; Küppers, F.J.E.M.; Salemink, C.A.; Vree, T.B.; Van Rossum, J.M. Cannabis. VII. Identification of cannabinol methyl ether from hashish. J. Chromatogr. A 1973, 81, 163-166. [CrossRef]

22. Chan, W.R.; Magnus, K.E.; Watson, H.A. The structure of cannabitriol. Experientia 1976, 32, 283-284. [CrossRef]

23. Friedrich-Fiechtl, J.; Spiteller, G. Neue cannabinoide-1. Tetrahedron 1975, 31, 479-487. [CrossRef]

24. Zou, S.; Kumar, U. Cannabinoid receptors and the endocannabinoid system: Signaling and function in the central nervous system. Int. J. Mol. Sci. 2018, 19, 833. [CrossRef] 
25. Deiana, S. Potential Medical Uses of Cannabigerol: A Brief Overview. In Handbook of Cannabis and Related Pathologies: Biology, Pharmacology, Diagnosis, and Treatment; Elsevier Inc.: Amsterdam, The Netherlands, 2017; pp. 958-967. ISBN 9780128008270.

26. Premoli, M.; Aria, F.; Bonini, S.A.; Maccarinelli, G.; Gianoncelli, A.; Pina, S.D.; Tambaro, S.; Memo, M.; Mastinu, A. Cannabidiol: Recent advances and new insights for neuropsychiatric disorders treatment. Life Sci. 2019, 224, 120-127. [CrossRef]

27. Metz, V.G.; da Rosa, J.L.O.; Rossato, D.R.; Milanesi, L.H.; Burger, M.E.; Pase, C.S. Cannabidiol prevents amphetamine relapse and modulates D1- and D2-receptor levels in mesocorticolimbic brain areas of rats. Eur. Neuropsychopharmacol. 2021, $50,23-33$. [CrossRef]

28. Friedman, L.K.; Wongvravit, J.P. Anticonvulsant and neuroprotective effects of cannabidiol during the juvenile period. J. Neuropathol. Exp. Neurol. 2018, 77, 904-919. [CrossRef]

29. Hawes, E.M.; Lee, C.R.; Brackney, D.E.; Ensley, T.G.; Kidd, J.; Page, C. Cannabidiol Products: Review of the Regulatory and Clinical Considerations. J. Nurse Pract. 2020, 16, 747-755. [CrossRef]

30. Martínez-Peña, A.A.; Perono, G.A.; Gritis, S.A.; Sharma, R.; Selvakumar, S.; Walker, O.S.; Gurm, H.; Holloway, A.C.; Raha, S. The impact of early life exposure to cannabis: The role of the endocannabinoid system. Int. J. Mol. Sci. 2021, 22, 8576. [CrossRef]

31. Fine, P.G.; Rosenfeld, M.J. The endocannabinoid system, cannabinoids, and pain. Rambam Maimonides Med. J. 2013, 4, e0022. [CrossRef]

32. Russo, E.B.; Marcu, J. Cannabis Pharmacology: The Usual Suspects and a Few Promising Leads. In Advances in Pharmacology; Academic Press Inc.: Oxford, UK, 2017; Volume 80, pp. 67-134.

33. Guzman, M. Cannabinoids: Potential anticancer agents. Nat. Rev. Cancer 2003, 3, 745-755. [CrossRef]

34. Hall, W.; MacDonald, C.; Currow, D. Cannabinoids and cancer: Causation, remediation, and palliation. Lancet. Oncol. 2005, 6, 35-42. [CrossRef]

35. Pisanti, S.; Picardi, P.; D'Alessandro, A.; Laezza, C.; Bifulco, M. The endocannabinoid signaling system in cancer. Trends Pharmacol. Sci. 2013, 34, 273-282. [CrossRef]

36. Donvito, G.; Nass, S.R.; Wilkerson, J.L.; Curry, Z.A.; Schurman, L.D.; Kinsey, S.G.; Lichtman, A.H. The Endogenous Cannabinoid System: A Budding Source of Targets for Treating Inflammatory and Neuropathic Pain. Neuropsychopharmacology 2018, 43, 52-79. [CrossRef] [PubMed]

37. Burstein, S.H.; Zurier, R.B. Cannabinoids, endocannabinoids, and related analogs in inflammation. AAPS J. 2009, 11, 109-119. [CrossRef] [PubMed]

38. Woodhams, S.G.; Sagar, D.R.; Burston, J.J.; Chapman, V. The role of the endocannabinoid system in pain. Handb. Exp. Pharmacol. 2015, 227, 119-143. [PubMed]

39. Taylor, A.H.; Ang, C.; Bell, S.C.; Konje, J.C. The role of the endocannabinoid system in gametogenesis, implantation and early pregnancy. Hum. Reprod. Update 2007, 13, 501-513. [CrossRef]

40. Gillies, R.; Lee, K.; Vanin, S.; Laviolette, S.R.; Holloway, A.C.; Arany, E.; Hardy, D.B. Maternal exposure to $\Delta$ 9-tetrahydrocannabinol impairs female offspring glucose homeostasis and endocrine pancreatic development in the rat. Reprod. Toxicol. 2020, 94, 84-91. [CrossRef]

41. Sun, X.; Dey, S.K. Endocannabinoid Signalingin Female Reproduction. ACS Chem. Neurosci. 2012, 3, 349. [CrossRef]

42. Warshak, C.R.; Regan, J.; Moore, B.; Magner, K.; Kritzer, S.; Van Hook, J. Association between marijuana use and adverse obstetrical and neonatal outcomes. J. Perinatol. 2015, 35, 991-995. [CrossRef]

43. Joshi, N.; Onaivi, E.S. Endocannabinoid system components: Overview and tissue distribution. Adv. Exp. Med. Biol. 2019, 1162, $1-12$.

44. González-Mariscal, I.; Krzysik-Walker, S.M.; Doyle, M.E.; Liu, Q.R.; Cimbro, R.; Santa-Cruz Calvo, S.; Ghosh, S.; Cieala, A.; Moaddel, R.; Carlson, O.D.; et al. Human CB1 receptor isoforms, present in hepatocytes and $\beta$-cells, are involved in regulating metabolism. Sci. Rep. 2016, 6, 33302. [CrossRef]

45. Mendizabal-Zubiaga, J.; Melser, S.; Bénard, G.; Ramos, A.; Reguero, L.; Arrabal, S.; Elezgarai, I.; Gerrikagoitia, I.; Suarez, J.; Rodríguez De Fonseca, F.; et al. Cannabinoid CB 1 receptors are localized in striated muscle mitochondria and regulate mitochondrial respiration. Front. Physiol. 2016, 7, 476. [CrossRef]

46. Tam, J.; Trembovler, V.; Di Marzo, V.; Petrosino, S.; Leo, G.; Alexandrovich, A.; Regev, A.; Casap, N.; Shteyer, A.; Ledent, C.; et al. The cannabinoid CB1 receptor regulates bone formation by modulating adrenergic signaling. FASEB J. 2008, 22, 285-294. [CrossRef]

47. Liu, Q.R.; Pan, C.H.; Hishimoto, A.; Li, C.Y.; Xi, Z.X.; Llorente-Berzal, A.; Viveros, M.P.; Ishiguro, H.; Arinami, T.; Onaivi, E.S.; et al. Species differences in cannabinoid receptor 2 (CNR2 gene): Identification of novel human and rodent CB2 isoforms, differential tissue expression and regulation by cannabinoid receptor ligands. Genes Brain Behav. 2009, 8, 519-530. [CrossRef]

48. Zhang, H.Y.; Bi, G.H.; Li, X.; Li, J.; Qu, H.; Zhang, S.J.; Li, C.Y.; Onaivi, E.S.; Gardner, E.L.; Xi, Z.X.; et al. Species differences in cannabinoid receptor 2 and receptor responses to cocaine self-administration in mice and rats. Neuropsychopharmacology 2015, 40, 1037-1051. [CrossRef]

49. Lu, H.C.; Mackie, K. Review of the endocannabinoid system. Biol. Psychiatry Cogn. Neurosci. Neuroimaging. $2021,6,607-615$.

50. Hebert-Chatelain, E.; Desprez, T.; Serrat, R.; Bellocchio, L.; Soria-Gomez, E.; Busquets-Garcia, A.; Pagano Zottola, A.C.; Delamarre, A.; Cannich, A.; Vincent, P.; et al. A cannabinoid link between mitochondria and memory. Nature 2016, 539, 555-559. [CrossRef]

51. Stanciu, G.D.; Ababei, D.C.; Bild, V.; Bild, W.; Paduraru, L.; Gutu, M.M.; Tamba, B.-I. Renal contributions in the pathophysiology and neuropathological substrates shared by chronic kidney disease and Alzheimer's disease. Brain Sci. 2020, 10, 563. [CrossRef] 
52. Di Marzo, V. New approaches and challenges to targeting the endocannabinoid system. Nat. Rev. Drug Discov. 2018, 17, 623-639. [CrossRef]

53. Di Marzo, V. Targeting the endocannabinoid system: To enhance or reduce? Nat. Rev. Drug Discov. 2008, 7, 438-455. [CrossRef]

54. An, D.; Peigneur, S.; Hendrickx, L.A.; Tytgat, J. Targeting Cannabinoid Receptors: Current Status and Prospects of Natural Products. Int. J. Mol. Sci. 2020, 21, 5064. [CrossRef]

55. Cristino, L.; Bisogno, T.; Di Marzo, V. Cannabinoids and the expanded endocannabinoid system in neurological disorders. Nat. Rev. Neurol. 2020, 16, 9-29. [CrossRef]

56. Maccarrone, M.; Finazzi-Agró, A. The endocannabinoid system, anandamide and the regulation of mammalian cell apoptosis. Cell Death Differ. 2003, 10, 946-955. [CrossRef]

57. Castillo, P.E.; Younts, T.J.; Chávez, A.E.; Hashimotodani, Y. Endocannabinoid Signaling and Synaptic Function. Neuron 2012, 76, 70-81. [CrossRef]

58. Chanda, D.; Neumann, D.; Glatz, J.F.C. The endocannabinoid system: Overview of an emerging multi-faceted therapeutic target. Prostaglandins Leukot. Essent. Fat. Acids 2019, 140, 51-56. [CrossRef]

59. Nicolussi, S.; Gertsch, J. Endocannabinoid transport revisited. Vitam. Horm. 2015, 98, 441-485.

60. Manz, K.M.; Ghose, D.; Turner, B.D.; Taylor, A.; Becker, J.; Grueter, C.A.; Grueter, B.A. Calcium-Permeable AMPA Receptors Promote Endocannabinoid Signaling at Parvalbumin Interneuron Synapses in the Nucleus Accumbens Core. Cell Rep. 2020, 32, 107971. [CrossRef]

61. Baggelaar, M.P.; Maccarrone, M.; van der Stelt, M. 2-Arachidonoylglycerol: A signaling lipid with manifold actions in the brain. Prog. Lipid Res. 2018, 71, 1-17. [CrossRef]

62. Micale, V.; Drago, F. Endocannabinoid system, stress and HPA axis. Eur. J. Pharmacol. 2018, 834, 230-239. [CrossRef]

63. Di Marzo, V.; De Petrocellis, L. Why do cannabinoid receptors have more than one endogenous ligand? Phil. Trans. R. Soc. B 2012, 367, 3216-3228. [CrossRef]

64. Hanuš, L.O.; Meyer, S.M.; Muñoz, E.; Taglialatela-Scafati, O.; Appendino, G. Phytocannabinoids: A unified critical inventory. Nat. Prod. Rep. 2016, 33, 1357-1392. [CrossRef]

65. Zagzoog, A.; Mohamed, K.A.; Kim, H.J.J.; Kim, E.D.; Frank, C.S.; Black, T.; Jadhav, P.D.; Holbrook, L.A.; Laprairie, R.B. In vitro and in vivo pharmacological activity of minor cannabinoids isolated from Cannabis sativa. Sci. Rep. 2020, $101,20405$.

66. Linciano, P.; Citti, C.; Luongo, L.; Belardo, C.; Maione, S.; Vandelli, M.A.; Forni, F.; Gigli, G.; Laganà, A.; Montone, C.M.; et al. Isolation of a high-affinity cannabinoid for the human CB1 receptor from a medicinal Cannabis sativa variety: $\Delta 9$ tetrahydrocannabutol, the butyl homologue of $\Delta$ 9-tetrahydrocannabinol. J. Nat. Prod. 2020, 83, 88-98. [CrossRef] [PubMed]

67. Navarro, G.; Varani, K.; Lillo, A.; Vincenzi, F.; Rivas-Santisteban, R.; Raïch, I.; Reyes-Resina, I.; Ferreiro-Vera, C.; Borea, P.A.; Sánchez de Medina, V.; et al. Pharmacological data of cannabidiol- and cannabigerol-type phytocannabinoids acting on cannabinoid CB1, CB2 and CB1/CB2 heteromer receptors. Pharmacol. Res. 2020, 159, 104940. [CrossRef] [PubMed]

68. Husni, A.S.; McCurdy, C.R.; Radwan, M.M.; Ahmed, S.A.; Slade, D.; Ross, S.A.; ElSohly, M.A.; Cutler, S.J. Evaluation of phytocannabinoids from high-potency Cannabis sativa using in vitro bioassays to determine structure-activity relationships for cannabinoid receptor 1 and cannabinoid receptor 2. Med. Chem. Res. 2014, 23, 4295-4300. [CrossRef] [PubMed]

69. Rosenthaler, S.; Pöhn, B.; Kolmanz, C.; Nguyen Huu, C.; Krewenka, C.; Huber, A.; Kranner, B.; Rausch, W.D.; Moldzio, R. Differences in receptor binding affinity of several phytocannabinoids do not explain their effects on neural cell cultures. Neurotoxicol. Teratol. 2014, 46, 49-56. [CrossRef]

70. Navarro, G.; Varani, K.; Reyes-Resina, I.; de Medina, V.S.; Rivas-Santisteban, R.; Callado, C.S.C.; Vincenzi, F.; Casano, S.; FerreiroVera, C.; Canela, E.I.; et al. Cannabigerol action at cannabinoid CB1 and CB2 receptors and at CB1-CB2 heteroreceptor complexes. Front. Pharmacol. 2018, 9, 632. [CrossRef]

71. Hua, T.; Vemuri, K.; Pu, M.; Qu, L.; Han, G.W.; Wu, Y.; Zhao, S.; Shui, W.; Li, S.; Korde, A.; et al. Crystal structure of the human cannabinoid receptor CB1. Cell 2016, 167, 750-762. [CrossRef]

72. De Petrocellis, L.; Ligresti, A.; Schiano Moriello, A.; Allarà, M.; Bisogno, T.; Petrosino, S.; Stott, C.G.; Marzo, V.D. Effects of cannabinoids and cannabinoid-enriched Cannabis extracts on TRP channels and endocannabinoid metabolic enzymes. Br. J. Pharmacol. 2011, 163, 1479-1494. [CrossRef]

73. De Freitas, R.L.; Salgado-Rohner, C.J.; Hallak, J.E.C.; De Souza Crippa, J.A.; Coimbra, N.C. Involvement of prelimbic medial prefrontal cortex in panic-like elaborated defensive behaviour and innate fear-induced antinociception elicited by GABAA receptor blockade in the dorsomedial and ventromedial hypothalamic nuclei: Role of the endocannabinoid. Int. J. Neuropsychopharmacol. 2013, 16, 1781-1798. [CrossRef]

74. Gugliandolo, A.; Pollastro, F.; Grassi, G.; Bramanti, P.; Mazzon, E. In vitro model of neuroinflammation: Efficacy of cannabigerol, a non-psychoactive cannabinoid. Int. J. Mol. Sci. 2018, 19, 1992. [CrossRef]

75. Lopatriello, A.; Caprioglio, D.; Minassi, A.; Schiano Moriello, A.; Formisano, C.; De Petrocellis, L.; Appendino, G.; TaglialatelaScafati, O. Iodine-mediated cyclization of cannabigerol (CBG) expands the cannabinoid biological and chemical space. Bioorg. Med. Chem. 2018, 26, 4532-4536. [CrossRef]

76. De Petrocellis, L.; Orlando, P.; Schiano Moriello, A.; Aviello, G.; Stott, C.; Izzo, A.A.; Di Marzo, V. Cannabinoid actions at TRPV channels: Effects on TRPV3 and TRPV4 and their potential relevance to gastrointestinal inflammation. Acta Physiol. 2012, 204, 255-266. [CrossRef] 
77. Borrelli, F.; Fasolino, I.; Romano, B.; Capasso, R.; Maiello, F.; Coppola, D.; Orlando, P.; Battista, G.; Pagano, E.; Di Marzo, V.; et al. Beneficial effect of the non-psychotropic plant cannabinoid cannabigerol on experimental inflammatory bowel disease. Biochem. Pharmacol. 2013, 85, 1306-1316. [CrossRef]

78. Ruhaak, L.R.; Felth, J.; Karlsson, P.C.; Rafter, J.J.; Verpoorte, R.; Bohlin, L. Evaluation of the Cyclooxygenase Inhibiting Effects of Six Major Cannabinoids Isolated from Cannabis sativa. Biol. Pharm. Bull. 2011, 34, 774-778. [CrossRef]

79. Smeriglio, A.; Giofrè, S.V.; Galati, E.M.; Monforte, M.T.; Cicero, N.; D'Angelo, V.; Grassi, G.; Circosta, C. Inhibition of aldose reductase activity by Cannabis sativa chemotypes extracts with high content of cannabidiol or cannabigerol. Fitoterapia 2018, 127, 101-108. [CrossRef]

80. D'Aniello, E.; Fellous, T.; Iannotti, F.A.; Gentile, A.; Allarà, M.; Balestrieri, F.; Gray, R.; Amodeo, P.; Vitale, R.M.; Di Marzo, V. Identification and characterization of phytocannabinoids as novel dual PPAR $\alpha / \gamma$ agonists by a computational and in vitro experimental approach. Biochim. Biophys. Acta-Gen. Subj. 2019, 1863, 586-597. [CrossRef]

81. Santoni, G.; Maggi, F.; Morelli, M.B.; Santoni, M.; Marinelli, O. Transient Receptor Potential Cation Channels in Cancer Therapy. Med. Sci. 2019, 7, 108. [CrossRef]

82. Urits, I.; Gress, K.; Charipova, K.; Habib, K.; Lee, D.; Lee, C.; Jung, J.W.; Kassem, H.; Cornett, E.; Paladini, A.; et al. Use of cannabidiol (CBD) for the treatment of chronic pain. Best Pract. Res. Clin. Anaesthesiol. 2020, 34, 463-477. [CrossRef]

83. Malvestio, R.B.; Medeiros, P.; Negrini-Ferrari, S.E.; Oliveira-Silva, M.; Medeiros, A.C.; Padovan, C.M.; Luongo, L.; Maione, S.; Coimbra, N.C.; de Freitas, R.L. Cannabidiol in the prelimbic cortex modulates the comorbid condition between the chronic neuropathic pain and depression-like behaviour in rats: The role of medial prefrontal cortex 5-HT1A and CB1 receptors. Brain Res. Bull. 2021, 174, 323-338. [CrossRef]

84. Joca, S.; Silote, G.P.; Sartim, A.; Sales, A.; Guimarães, F.; Wegener, G. Putative effects of cannabidiol in depression and synaptic plasticity. In The Neuroscience of Depression; Elsevier: Amsterdam, The Netherlands, 2021; pp. 459-467.

85. Zanelati, T.V.; Biojone, C.; Moreira, F.A.; Guimarães, F.S.; Joca, S.R.L. Antidepressant-like effects of cannabidiol in mice: Possible involvement of 5-HT 1A receptors. Br. J. Pharmacol. 2010, 159, 122-128. [CrossRef]

86. Stanciu, G.D.; Bild, V.; Ababei, D.C.; Rusu, R.N.; Cobzaru, A.; Paduraru, L.; Bulea, D. Link between diabetes and Alzheimer's disease due to the shared amyloid aggregation and deposition involving both neurodegenerative changes and neurovascular damages. J. Clin. Med. 2020, 9, 1713. [CrossRef]

87. Franco, V.; Perucca, E. Pharmacological and Therapeutic Properties of Cannabidiol for Epilepsy. Drugs 2019, 79, 1435-1454. [CrossRef]

88. Iannotti, F.A.; Hill, C.L.; Leo, A.; Alhusaini, A.; Soubrane, C.; Mazzarella, E.; Russo, E.; Whalley, B.J.; Di Marzo, V.; Stephens, G.J. Nonpsychotropic Plant Cannabinoids, Cannabidivarin (CBDV) and Cannabidiol (CBD), Activate and Desensitize Transient Receptor Potential Vanilloid 1 (TRPV1) Channels in Vitro: Potential for the Treatment of Neuronal Hyperexcitability. ACS Chem. Neurosci. 2014, 5, 1131-1141. [CrossRef]

89. Kaplan, J.S.; Stella, N.; Catterall, W.A.; Westenbroek, R.E. Cannabidiol attenuates seizures and social deficits in a mouse model of Dravet syndrome. Proc. Natl. Acad. Sci. USA 2017, 114, 11229-11234. [CrossRef]

90. Laun, A.S.; Shrader, S.H.; Brown, K.J.; Song, Z.-H. GPR3, GPR6, and GPR12 as novel molecular targets: Their biological functions and interaction with cannabidiol. Acta Pharmacol. Sin. 2019, 40, 300-308. [CrossRef]

91. Pagano, E.; Romano, B.; Iannotti, F.A.; Parisi, O.A.; D'Armiento, M.; Pignatiello, S.; Coretti, L.; Lucafò, M.; Venneri, T.; Stocco, G.; et al. The non-euphoric phytocannabinoid cannabidivarin counteracts intestinal inflammation in mice and cytokine expression in biopsies from UC pediatric patients. Pharmacol. Res. 2019, 149, 104464. [CrossRef]

92. Bolognini, D.; Rock, E.M.; Cluny, N.L.; Cascio, M.G.; Limebeer, C.L.; Duncan, M.; Stott, C.G.; Javid, F.A.; Parker, L.A.; Pertwee, R.G. Cannabidiolic acid prevents vomiting in Suncus murinus and nausea-induced behaviour in rats by enhancing 5-HT1A receptor activation. Br. J. Pharmacol. 2013, 168, 1456-1470. [CrossRef]

93. Rock, E.M.; Sullivan, M.T.; Collins, S.A.; Goodman, H.; Limebeer, C.L.; Mechoulam, R.; Parker, L.A. Evaluation of repeated or acute treatment with cannabidiol (CBD), cannabidiolic acid (CBDA) or CBDA methyl ester (HU-580) on nausea and/or vomiting in rats and shrews. Psychopharmacology 2020, 237, 2621-2631. [CrossRef]

94. Takeda, S.; Okajima, S.; Miyoshi, H.; Yoshida, K.; Okamoto, Y.; Okada, T.; Amamoto, T.; Watanabe, K.; Omiecinski, C.J.; Aramaki, H. Cannabidiolic acid, a major cannabinoid in fiber-type cannabis, is an inhibitor of MDA-MB-231 breast cancer cell migration. Toxicol. Lett. 2012, 214, 314-319. [CrossRef]

95. Yuan, M.; Kiertscher, S.M.; Cheng, Q.; Zoumalan, R.; Tashkin, D.P.; Roth, M.D. $\Delta$ 9-Tetrahydrocannabinol regulates Th1/Th2 cytokine balance in activated human T cells. J. Neuroimmunol. 2002, 133, 124-131. [CrossRef]

96. Butovsky, E.; Juknat, A.; Goncharov, I.; Elbaz, J.; Eilam, R.; Zangen, A.; Vogel, Z. In vivo up-regulation of brain-derived neurotrophic factor in specific brain areas by chronic exposure to $\Delta$ 9-tetrahydrocannabinol. J. Neurochem. 2005, 93, 802-811. [CrossRef] [PubMed]

97. Marsicano, G.; Lafenêtre, P. Roles of the Endocannabinoid System in Learning and Memory. Curr. Top. Behav. Neurosci. 2009, 1, 201-230. [PubMed]

98. Sido, J.M.; Yang, X.; Nagarkatti, P.S.; Nagarkatti, M. $\Delta$ 9-Tetrahydrocannabinol-mediated epigenetic modifications elicit myeloidderived suppressor cell activation via STAT3/S100A8. J. Leukoc. Biol. 2015, 97, 677-688. [CrossRef] [PubMed]

99. Eubanks, L.M.; Rogers, C.J.; Beuscher, A.E.; Koob, G.F.; Olson, A.J.; Dickerson, T.J.; Janda, K.D. A molecular link between the active component of marijuana and Alzheimer's disease pathology. Mol. Pharm. 2006, 3, 773-777. [CrossRef] [PubMed] 
100. Cao, C.; Li, Y.; Liu, H.; Bai, G.; Mayl, J.; Lin, X.; Sutherland, K.; Nabar, N.; Cai, J. The potential therapeutic effects of THC on Alzheimer's disease. J. Alzheimers Dis 2014, 42, 973-984. [CrossRef]

101. Neeper, M.P.; Liu, Y.; Hutchinson, T.L.; Wang, Y.; Flores, C.M.; Qin, N. Activation Properties of Heterologously Expressed Mammalian TRPV2. J. Biol. Chem. 2007, 282, 15894-15902. [CrossRef]

102. De Petrocellis, L.; Vellani, V.; Schiano-Moriello, A.; Marini, P.; Magherini, P.C.; Orlando, P.; Marzo, V. Di Plant-derived cannabinoids modulate the activity of transient receptor potential channels of ankyrin type-1 and melastatin type-8. J. Pharmacol. Exp. Ther. 2008, 325, 1007-1015. [CrossRef]

103. Showalter, V.M.; Compton, D.R.; Martin, B.R.; Abood, M.E. Evaluation of binding in a transfected cell line expressing a peripheral cannabinoid receptor (CB2): Identification of cannabinoid receptor subtype selective ligands. J. Pharmacol Exp. Ther 1996, 8 , 989-999.

104. Nadal, X.; Río, C.; del Casano, S.; Palomares, B.; Ferreiro-Vera, C.; Navarrete, C.; Sánchez-Carnerero, C.; Cantarero, I.; Bellido, M.L.; Meyer, S.; et al. Tetrahydrocannabinolic acid is a potent PPAR $\gamma$ agonist with neuroprotective activity. Br. J. Pharmacol. 2017, 174, 4263-4276. [CrossRef]

105. Grunfeld, Y.; Ei, H. Psychopharmacological activity of the active constituents of hashish and some related cannabinoids. Psychopharmacologia 1969, 14, 200-210. [CrossRef]

106. Zirpel, B.; Degenhardt, F.; Martin, C.; Kayser, O.; Stehle, F. Engineering yeasts as platform organisms for cannabinoid biosynthesis. J. Biotechnol. 2017, 259, 204-212. [CrossRef]

107. Shoyama, Y.; Yagi, M.; Nishioka, I.; Yamauchi, T. Biosynthesis of cannabinoid acids. Phytochemistry 1975, 14, 2189-2192. [CrossRef]

108. Shoyama, Y.; Hirano, H.; Makino, H.; Umekita, N. The isolation and structure of four new propyl cannabis acids, tetrahydrocannabivarinic acid, cannabidivarinic acid, cannabichromevarinic acid and cannabigerovarinic acid from Thai Cannabis, 'Meao Variant'. Chem. Pharm. Bull. 1977, 25, 2306-2311. [CrossRef]

109. Elsohly, H.N.; Turner, C.E.; Clark, A.M.; Elsohly, M.A. Synthesis and Antimicrobial Activities of Certain Cannabichromene and Cannabigerol Related Compounds. J. Pharm. Sci. 1982, 71, 1319-1323. [CrossRef]

110. Appendino, G.; Gibbons, S.; Giana, A.; Pagani, A.; Grassi, G.; Stavri, M.; Smith, E.; Rahman, M.M. Antibacterial cannabinoids from Cannabis sativa: A structure-activity study. J. Nat. Prod. 2008, 71, 1427-1430. [CrossRef]

111. Borrelli, F.; Pagano, E.; Romano, B.; Panzera, S.; Maiello, F.; Coppola, D.; De Petrocellis, L.; Buono, L.; Orlando, P.; Izzo, A.A. Colon carcinogenesis is inhibited by the TRPM8 antagonist cannabigerol, a Cannabis-derived non-psychotropic cannabinoid. Carcinogenesis 2014, 35, 2787-2797. [CrossRef]

112. Baraldi, P.G.; Preti, D.; Materazzi, S.; Geppetti, P. Transient receptor potential ankyrin 1 (TRPA1) channel as emerging target for novel analgesics and anti-inflammatory agents. J. Med. Chem. 2010, 53, 5085-5107. [CrossRef]

113. Di Marzo, V.; Piscitelli, F. The endocannabinoid system and its modulation by phytocannabinoids. Neurotherapeutics 2015, 12 , 692-698. [CrossRef]

114. Morita, T.; Mitsuyama, K.; Yamasaki, H.; Mori, A.; Yoshimura, T.; Araki, T.; Morita, M.; Tsuruta, K.; Yamasaki, S.; Kuwaki, K.; et al. Gene expression of transient receptor potential channels in peripheral blood mononuclear cells of inflammatory bowel disease patients. J. Clin. Med. 2020, 9, 2643. [CrossRef]

115. International Cannabinoid Research Society. 22nd Annual Symposium of the International Cannabinoid Research Society; International Cannabinoid Research Society: Freiburg im Breisgau, Germany, 2012; ISBN 9780965805353.

116. Baek, S.-H.; Seok Han, D.; Nam Yook, C.; Chae Kim, Y.; Suk Kwak, J. Synthesis and antitumor activity of cannabigerol. Arch. Pharm. Res. 1996, 19, 228-230. [CrossRef]

117. Hwa Baek, S.; Ok Kim, Y.; Suk Kwag, J.; Eun Choi, K.; Young Jung, W.; Seok Han, D. Boron Trifluoride Etherate on Silica-A Modified Lewis Acid Reagent (VII). In Antitumor Activity of Cannabigerol Against Human Oral Epitheloid Carcinoma Cells; Bentham Science Publishers: Sharjah, United Arab Emirates, 1998; Volume 21.

118. Bujak, J.K.; Kosmala, D.; Szopa, I.M.; Majchrzak, K.; Bednarczyk, P. Inflammation, cancer and immunity-implication of TRPV1 channel. Front. Oncol. 2019, 9, 1087-1103. [CrossRef]

119. Nallathambi, R.; Mazuz, M.; Namdar, D.; Shik, M.; Namintzer, D.; Vinayaka, A.C.; Ion, A.; Faigenboim, A.; Nasser, A.; Laish, I.; et al. Identification of synergistic interaction between cannabis-derived compounds for cytotoxic activity in colorectal cancer cell lines and colon polyps that induces apoptosis-related cell death and distinct gene expression. Cannabis Cannabinoid Res. 2018, 3, 120-135. [CrossRef] [PubMed]

120. Marsch, R.; Foeller, E.; Rammes, G.; Bunck, M.; Kössl, M.; Holsboer, F.; Zieglgänsberger, W.; Landgraf, R.; Lutz, B.; Wotjak, C.T. Reduced anxiety, conditioned fear, and hippocampal long-term potentiation in transient receptor potential vanilloid type 1 receptor-deficient mice. J. Neurosci. 2007, 27, 832-839. [CrossRef] [PubMed]

121. Caterina, M.J.; Leffler, A.; Malmberg, A.B.; Martin, W.J.; Trafton, J.; Petersen-Zeitz, K.R.; Koltzenburg, M.; Basbaum, A.I.; Julius, D. Impaired nociception and pain sensation in mice lacking the capsaicin receptor. Science 2000, 288, 306-313. [CrossRef] [PubMed]

122. Marinelli, S.; Di Marzo, V.; Berretta, N.; Matias, I.; Maccarrone, M.; Bernardi, G.; Mercuri, N.B. Presynaptic facilitation of glutamatergic synapses to dopaminergic neurons of the rat substantia nigra by endogenous stimulation of vanilloid receptors. $J$. Neurosci. 2003, 23, 3136-3144. [CrossRef]

123. Granja, A.G.; Carrillo-Salinas, F.; Pagani, A.; Gómez-Cañas, M.; Negri, R.; Navarrete, C.; Mecha, M.; Mestre, L.; Fiebich, B.L.; Cantarero, I.; et al. A cannabigerol quinone alleviates neuroinflammation in a chronic model of multiple sclerosis. J. Neuroimmune Pharmacol. 2012, 7, 1002-1016. [CrossRef] 
124. Valdeolivas, S.; Navarrete, C.; Cantarero, I.; Bellido, M.L.; Muñoz, E.; Sagredo, O. Neuroprotective properties of cannabigerol in Huntington's disease: Studies in R6/2 mice and 3-nitropropionate-lesioned mice. Neurotherapeutics 2015, 12, 185-199. [CrossRef]

125. Schubert, D.; Kepchia, D.; Liang, Z.; Dargusch, R.; Goldberg, J.; Maher, P. Efficacy of cannabinoids in a pre-clinical drug-screening platform for Alzheimer's disease. Mol. Neurobiol. 2019, 56, 7719-7730. [CrossRef]

126. Stanciu, G.D.; Rusu, R.N.; Bild, V.; Filipiuc, L.E.; Tamba, B.I.; Ababei, D.C. Systemic actions of SGLT2 inhibition on chronic mTOR activation as a shared pathogenic mechanism between alzheimer's disease and diabetes. Biomedicines 2021, 9, 576. [CrossRef]

127. Brierley, D.I.; Samuels, J.; Duncan, M.; Whalley, B.J.; Williams, C.M. Cannabigerol is a novel, well-tolerated appetite stimulant in pre-satiated rats. Psychopharmacology 2016, 233, 3603-3613. [CrossRef]

128. Farha, M.A.; El-Halfawy, O.M.; Gale, R.T.; Macnair, C.R.; Carfrae, L.A.; Zhang, X.; Jentsch, N.G.; Magolan, J.; Brown, E.D. Uncovering the hidden antibiotic potential of Cannabis. ACS Infect. Dis. 2020, 6, 338-346. [CrossRef]

129. Wilkinson, J.D.; Williamson, E.M. Cannabinoids inhibit human keratinocyte proliferation through a non-CB1/CB2 mechanism and have a potential therapeutic value in the treatment of psoriasis. J. Dermatol. Sci. 2007, 45, 87-92. [CrossRef]

130. Pucci, M.; Rapino, C.; Di Francesco, A.; Dainese, E.; D'Addario, C.; Maccarrone, M. Epigenetic control of skin differentiation genes by phytocannabinoids. Br. J. Pharmacol. 2013, 170, 581-591. [CrossRef]

131. Pedrazzi, J.F.C.; Sales, A.J.; Guimarães, F.S.; Joca, S.R.L.; Crippa, J.A.S.; Del Bel, E. Cannabidiol prevents disruptions in sensorimotor gating induced by psychotomimetic drugs that last for 24-h with probable involvement of epigenetic changes in the ventral striatum. Prog. Neuro-Psychopharmacol. Biol. Psychiatry 2021, 111, 110352. [CrossRef]

132. Khan, A.A.; Shekh-Ahmad, T.; Khalil, A.; Walker, M.C.; Ali, A.B. Cannabidiol exerts antiepileptic effects by restoring hippocampal interneuron functions in a temporal lobe epilepsy model. Br. J. Pharmacol. 2018, 175, 2097-2115. [CrossRef]

133. Shbiro, L.; Hen-Shoval, D.; Hazut, N.; Rapps, K.; Dar, S.; Zalsman, G.; Mechoulam, R.; Weller, A.; Shoval, G. Effects of cannabidiol in males and females in two different rat models of depression. Physiol. Behav. 2019, 201, 59-63. [CrossRef]

134. Rock, E.M.; Limebeer, C.L.; Parker, L.A. Effect of cannabidiolic acid and $\Delta 9$-tetrahydrocannabinol on carrageenan-induced hyperalgesia and edema in a rodent model of inflammatory pain. Psychopharmacology 2018, 235, 3259-3271. [CrossRef]

135. Anderson, L.L.; Low, I.K.; Banister, S.D.; McGregor, I.S.; Arnold, J.C. Pharmacokinetics of phytocannabinoid acids and anticonvulsant effect of cannabidiolic acid in a mouse model of Dravet syndrome. J. Nat. Prod. 2019, 82, 3047-3055. [CrossRef]

136. Vollner, L.; Bieniek, D.; Korte, F. Cannabidivarin, a new hashish constituent. Tetrahedron Lett. 1969, 3, 145-147. [CrossRef]

137. Ibeas Bih, C.; Chen, T.; Nunn, A.V.W.; Bazelot, M.; Dallas, M.; Whalley, B.J. Molecular targets of cannabidiol in neurological disorders. Neurotherapeutics 2015, 12, 699-730. [CrossRef]

138. Shrader, S.H.; Tong, Y.-G.; Duff, M.B.; Freedman, J.H.; Song, Z.-H. Involvement of dopamine receptor in the actions of nonpsychoactive phytocannabinoids. Biochem. Biophys. Res. Commun. 2020, 533, 1366-1370. [CrossRef]

139. Martin, L.J.; Banister, S.D.; Bowen, M.T. Understanding the complex pharmacology of cannabidiol: Mounting evidence suggests a common binding site with cholesterol. Pharmacol. Res. 2021, 166, 105508. [CrossRef]

140. Sylantyev, S.; Jensen, T.P.; Ross, R.A.; Rusakov, D.A. Cannabinoid- and lysophosphatidylinositol-sensitive receptor GPR55 boosts neurotransmitter release at central synapses. Proc. Natl. Acad. Sci. USA 2013, 110, 5193-5198. [CrossRef]

141. Pretzsch, C.M.; Voinescu, B.; Lythgoe, D.; Horder, J.; Mendez, M.A.; Wichers, R.; Ajram, L.; Ivin, G.; Heasman, M.; Edden, R.A.E.; et al. Effects of cannabidivarin (CBDV) on brain excitation and inhibition systems in adults with and without Autism Spectrum Disorder (ASD): A single dose trial during magnetic resonance spectroscopy. Transl. Psychiatry 2019, 9, 313. [CrossRef]

142. Zamberletti, E.; Gabaglio, M.; Piscitelli, F.; Brodie, J.S.; Woolley-Roberts, M.; Barbiero, I.; Tramarin, M.; Binelli, G.; Landsberger, N.; Kilstrup-Nielsen, C.; et al. Cannabidivarin completely rescues cognitive deficits and delays neurological and motor defects in male Mecp2 mutant mice. J. Psychopharmacol. 2019, 33, 894-907. [CrossRef]

143. Vigli, D.; Cosentino, L.; Raggi, C.; Laviola, G.; Woolley-Roberts, M.; De Filippis, B. Chronic treatment with the phytocannabinoid Cannabidivarin (CBDV) rescues behavioural alterations and brain atrophy in a mouse model of Rett syndrome. Neuropharmacology 2018, 140, 121-129. [CrossRef]

144. Hindocha, C.; Freeman, T.P.; Schafer, G.; Gardener, C.; Das, R.K.; Morgan, C.J.A.; Curran, H.V. Acute effects of delta-9tetrahydrocannabinol, cannabidiol and their combination on facial emotion recognition: A randomised, double-blind, placebocontrolled study in cannabis users. Eur. Neuropsychopharmacol. 2015, 25, 325-334. [CrossRef]

145. VanDolah, H.J.; Bauer, B.A.; Mauck, K.F. Clinicians' Guide to Cannabidiol and Hemp Oils. Mayo Clin. Proc. 2019, $94,1840-1851$. [CrossRef] [PubMed]

146. Franco, V.; Bialer, M.; Perucca, E. Cannabidiol in the treatment of epilepsy: Current evidence and perspectives for further research. Neuropharmacology 2021, 185, 108442. [CrossRef] [PubMed]

147. Anavi-Goffer, S.; Baillie, G.; Irving, A.J.; Gertsch, J.; Greig, I.R.; Pertwee, R.G.; Ross, R.A. Modulation of L- $\alpha$-lysophosphatidylinositol/GPR5 mitogen-activated protein kinase (MAPK) signaling by cannabinoids. J. Biol. Chem. 2012, 287, 91-104. [CrossRef] [PubMed]

148. Zamberletti, E.; Gabaglio, M.; Woolley-Roberts, M.; Bingham, S.; Rubino, T.; Parolaro, D. Cannabidivarin treatment ameliorates Autism-like behaviors and restores hippocampal endocannabinoid system and glia alterations induced by prenatal valproic acid exposure in rats. Front. Cell. Neurosci. 2019, 13, 367. [CrossRef] [PubMed]

149. Turner, S.; Barker, V.D.; Adams, A.A. Effects of cannabidiol on the in vitro lymphocyte pro-inflammatory cytokine production of senior horses. J. Equine Vet. Sci. 2021, 103, 103668. [CrossRef]

150. Stone, N.L.; England, T.J.; O'Sullivan, S.E. Protective effects of cannabidivarin and cannabigerol on cells of the blood-brain barrier under ischemic conditions. Cannabis Cannabinoid Res. 2021, 6, 315-326. [CrossRef] 
151. Martín-Moreno, A.M.; Reigada, D.; Ramírez, B.G.; Mechoulam, R.; Innamorato, N.; Cuadrado, A.; de Ceballos, M.L. Cannabidiol and other cannabinoids reduce microglial activation in vitro and in vivo: Relevance to Alzheimer's disease. Mol. Pharmacol. 2011, 79, 964-973. [CrossRef]

152. Gazarini, L.; Stern, C.A.J.; Piornedo, R.R.; Takahashi, R.N.; Bertoglio, L.J. PTSD-Like Memory generated through enhanced noradrenergic activity is mitigated by a dual step pharmacological intervention targeting its reconsolidation. Int. J. Neuropsychopharmacol. 2015, 18, pyu026. [CrossRef]

153. McAllister, S.D.; Christian, R.T.; Horowitz, M.P.; Garcia, A.; Desprez, P.Y. Cannabidiol as a novel inhibitor of Id-1 gene expression in aggressive breast cancer cells. Mol. Cancer Ther. 2007, 6, 2921-2927. [CrossRef]

154. Hegde, V.L.; Hegde, S.; Cravatt, B.F.; Hofseth, L.J.; Nagarkatti, M.; Nagarkatti, P.S. Attenuation of experimental autoimmune hepatitis by exogenous and endogenous cannabinoids: Involvement of regulatory T cells. Mol. Pharmacol. 2008, 74, 20-33. [CrossRef]

155. McKallip, R.J.; Lombard, C.; Martin, B.R.; Nagarkatti, M.; Nagarkatti, P.S. $\Delta$ 9-tetrahydrocannabinol-induced apoptosis in the thymus and spleen as a mechanism of immunosuppression in vitro and in vivo. J. Pharmacol. Exp. Ther. 2002, 302, 451-465. [CrossRef]

156. Jarbe, T.U.C.; Henriksson, B.G. Acute effects of two tetrahydrocannabinols ( $\triangle 9$-THC and $\triangle 8$-THC) on water intake in water deprived rats: Implications for behavioral studies on marijuana compounds. Psychopharmacologia 1973, 30, 315-322. [CrossRef]

157. Palomares, B.; Ruiz-Pino, F.; Garrido-Rodriguez, M.; Eugenia Prados, M.; Sánchez-Garrido, M.A.; Velasco, I.; Vazquez, M.J.; Nadal, X.; Ferreiro-Vera, C.; Morrugares, R.; et al. Tetrahydrocannabinolic acid A (THCA-A) reduces adiposity and prevents metabolic disease caused by diet-induced obesity. Biochem. Pharmacol. 2020, 171, 113693. [CrossRef]

158. Devinsky, O.; Cross, J.H.; Laux, L.; Marsh, E.; Miller, I.; Nabbout, R.; Scheffer, I.E.; Thiele, E.A.; Wright, S. Trial of cannabidiol for drug-resistant seizures in the Dravet syndrome. N. Engl. J. Med. 2017, 376, 2011-2020. [CrossRef]

159. Miller, I.; Scheffer, I.E.; Gunning, B.; Sanchez-Carpintero, R.; Gil-Nagel, A.; Perry, M.S.; Saneto, R.P.; Checketts, D.; Dunayevich, E.; Knappertz, V. Dose-ranging effect of adjunctive oral cannabidiol vs placebo on convulsive seizure frequency in Dravet syndrome. JAMA Neurol. 2020, 77, 613-621. [CrossRef]

160. Devinsky, O.; Patel, A.D.; Cross, J.H.; Villanueva, V.; Wirrell, E.C.; Privitera, M.; Greenwood, S.M.; Roberts, C.; Checketts, D.; VanLandingham, K.E.; et al. Effect of cannabidiol on drop seizures in the Lennox-Gastaut syndrome. N. Engl. J. Med. 2018, 378, 1888-1897. [CrossRef]

161. Hotz, J.; Fehlmann, B.; Papassotiropoulos, A.; de Quervain, D.J.; Schicktanz, N.S. Cannabidiol enhances verbal episodic memory in healthy young participants: A randomized clinical trial. J. Psychiatr. Res. 2021, 143, 327-333. [CrossRef]

162. D’Souza, D.C.; Perry, E.; MacDougall, L.; Ammerman, Y.; Cooper, T.; Wu, Y.; Braley, G.; Gueorguieva, R.; Krystal, J.H. The psychotomimetic effects of intravenous delta-9-tetrahydrocannabinol in healthy individuals: Implications for psychosis. Neuropsychopharmacology 2004, 29, 1558-1572. [CrossRef]

163. Rieder, S.A.; Chauhan, A.; Singh, U.; Nagarkatti, M.; Nagarkatti, P. Cannabinoid-induced apoptosis in immune cells as a pathway to immunosuppression. Immunobiology 2010, 215, 598-605. [CrossRef]

164. Mohammed, A.; Alghetaa, H.; Sultan, M.; Singh, N.P.; Nagarkatti, P.; Nagarkatti, M. Administration of $\Delta 9$-tetrahydrocannabinol (THC) post-staphylococcal enterotoxin B exposure protects mice from acute Respiratory Distress syndrome and toxicity. Front. Pharmacol. 2020, 11, 893. [CrossRef]

165. Suliman, N.A.; Taib, C.N.M.; Moklas, M.A.M.; Basir, R. Delta-9-tetrahydrocannabinol ( $\Delta 9$-THC) induce neurogenesis and improve cognitive performances of male Sprague Dawley rats. Neurotox. Res. 2018, 33, 402-411. [CrossRef]

166. Amin, M.R.; Ali, D.W. Pharmacology of medical Cannabis. Adv. Exp. Med. Biol. 2019, 1162, 151-165.

167. Boggs, D.L.; Nguyen, J.D.; Morgenson, D.; Taffe, M.A.; Ranganathan, M. Clinical and preclinical evidence for functional interactions of cannabidiol and $\Delta$-tetrahydrocannabinol. Neuropsychopharmacology 2018, 43, 142-154. [CrossRef]

168. Pertwee, R.G. The diverse CB1 and CB2 receptor pharmacology of three plant cannabinoids: $\Delta$ 9-tetrahydrocannabinol, cannabidiol and $\Delta$ 9-tetrahydrocannabivarin. Br. J. Pharmacol. 2008, 153, 199-215. [CrossRef]

169. Turner, S.E.; Williams, C.M.; Iversen, L.; Whalley, B.J. Molecular pharmacology of phytocannabinoids. Prog. Chem. Org. Nat. Prod. 2017, 103, 61-101. [PubMed]

170. Iwamura, H.; Suzuki, H.; Ueda, Y.; Kaya, T.; Inaba, T. In vitro and in vivo pharmacological characterization of JTE-907, a novel selective ligand for cannabinoid CB2 receptor. J. Pharmacol. Exp. Ther. 2001, 296, 420-425. [PubMed]

171. Rinaldi-Carmona, M.; Barth, F.; Héaulme, M.; Shire, D.; Calandra, B.; Congy, C.; Martinez, S.; Maruani, J.; Néliat, G.; Caput, D. SR141716A, a potent and selective antagonist of the brain cannabinoid receptor. FEBS Lett. 1994, 350, 240-244. [CrossRef]

172. Bayewitch, M.; Rhee, M.-H.; Avidor-Reiss, T.; Breuer, A.; Mechoulam, R.; Vogel, Z. (一)- $\Delta 9$-tetrahydrocannabinol antagonizes the peripheral cannabinoid receptor-mediated inhibition of adenylyl cyclase. Int. J. Biol. Chem. 1996, 271, 9902-9905. [CrossRef]

173. Thomas, A.; Stevenson, L.A.; Wease, K.N.; Price, M.R.; Baillie, G.; Ross, R.A.; Pertwee, R.G. Evidence that the plant cannabinoid $\Delta$ 9-tetrahydrocannabivarin is a cannabinoid CB1 and CB receptor antagonist. Br. J. Pharmacol. 2005, 146, 917-926. [CrossRef]

174. Huffman, J.W.; Liddle, J.; Yu, S.; Aung, M.M.; Abood, M.E.; Wiley, J.L.; Martin, B.R. 3-(1' ,1'-Dimethylbutyl)-1-deoxy- $\Delta 8$-THC and related compounds: Synthesis of selective ligands for the CB2 receptor. Bioorg. Med. Chem. 1999, 7, 2905-2914. [CrossRef]

175. Busch-Petersen, J.; Hill, W.A.; Fan, P.; Khanolkar, A.; Xie, X.-Q.; Tius, M.A.; Makriyannis, A. Unsaturated side chain $\beta-11-$ hydroxyhexahydrocannabinol analogs. J. Med. Chem. 1996, 39, 3790-3796. [CrossRef] 
176. Bolognini, D.; Costa, B.; Maione, S.; Comelli, F.; Marini, P.; Di Marzo, V.; Parolaro, D.; Ross, R.A.; Gauson, L.A.; Cascio, M.G.; et al. The plant cannabinoid $\Delta$ 9-tetrahydrocannabivarin can decrease signs of inflammation and inflammatory pain in mice. Br. J. Pharmacol. 2010, 160, 677-687. [CrossRef]

177. Rock, E.M.; Kopstick, R.L.; Limebeer, C.L.; Parker, L.A. Tetrahydrocannabinolic acid reduces nausea-induced conditioned gaping in rats and vomiting in Suncus murinus. Br. J. Pharmacol. 2013, 170, 641-648. [CrossRef]

178. Moreno-Sanz, G. Can You Pass the Acid Test? Critical Review and Novel Therapeutic Perspectives of $\Delta^{9}$-Tetrahydrocannabinolic Acid A. Cannabis Cannabinoid Res. 2016, 1, 124-130. [CrossRef]

179. Verhoeckx, K.C.M.; Korthout, H.A.A.J.; van Meeteren-Kreikamp, A.P.; Ehlert, K.A.; Wang, M.; van der Greef, J.; Rodenburg, R.J.T.; Witkamp, R.F. Unheated Cannabis sativa extracts and its major compound THC-acid have potential immuno-modulating properties not mediated by CB1 and CB2 receptor coupled pathways. Int. Immunopharmacol. 2006, 6, 656-665. [CrossRef]

180. Ahmed, S.A.; Ross, S.A.; Slade, D.; Radwan, M.M.; Zulfiqar, F.; ElSohly, M.A. Cannabinoid ester constituents from high-potency. Cannabis sativa. J. Nat. Prod. 2008, 71, 536-542. [CrossRef]

181. Mcpartland, J.M.; Macdonald, C.; Young, M.; Grant, P.S.; Furkert, D.P.; Glass, M. Affinity and efficacy studies of tetrahydrocannabinolic acid A at cannabinoid receptor types one and two. Cannabis Cannabinoid Res. 2017, 2, 87-95. [CrossRef]

182. Morales, P.; Reggio, P.H. An update on Non-CB1, Non-CB2 cannabinoid related G-protein-coupled receptors. Cannabis Cannabinoid Res. 2017, 2, 265-273. [CrossRef]

183. Jordt, S.-E.; Bautista, D.M.; Chuang, H.; McKemy, D.D.; Zygmunt, P.M.; Högestätt, E.D.; Meng, I.D.; Julius, D. Mustard oils and cannabinoids excite sensory nerve fibres through the TRP channel ANKTM1. Nature 2004, 427, 260-265. [CrossRef]

184. Devane, W.A.; Dysarz Iii, F.A.; Johnson, M.R.; Melvin, L.S.; Howlett, A.C. Determination and Characterization of a Cannabinoid Receptor in Rat Brain. Mol. Pharmacol. 1988, 34, 605-613.

185. Mechoulam, R.; Feigenbaum, J.J.; Lander, N.; Segal, M.; Järbe, T.U.C.; Hiltunen, A.J.; Consroe, P. Enantiomeric cannabinoids: Stereospecificity of psychotropic activity. Experientia 1988, 44, 762-764. [CrossRef]

186. LaBuda, C.J.; Koblish, M.; Little, P.J. Cannabinoid CB2 receptor agonist activity in the hindpaw incision: Model of postoperative pain. Eur. J. Pharmacol. 2005, 527, 172-174. [CrossRef]

187. Shevyrin, V.A.; Morzherin, Y.Y. Cannabinoids: Structures, effects, and classification. Russ. Chem. Bull. 2015, 64, 1249-1266. [CrossRef]

188. Andersson, D.A.; Gentry, C.; Alenmyr, L.; Killander, D.; Lewis, S.E.; Andersson, A.; Bucher, B.; Galzi, J.L.; Sterner, O.; Bevan, S.; et al. TRPA1 mediates spinal antinociception induced by acetaminophen and the cannabinoid $\Delta 9$-tetrahydrocannabiorcol. Nat. Commun. 2011, 2, 551. [CrossRef]

189. Martin, B.R.; Jefferson, R.; Winckler, R.; Wiley, J.L.; Huffman, J.W.; Crocker, P.J.; Saha, B.; Razdan, R.K. Manipulation of the tetrahydrocannabinol side chain delineates agonists, partial agonists, and antagonists. J. Pharm. Exper. Therapeutics 1999, 290, 1065-1079.

190. Bow, E.W.; Rimoldi, J.M. The structure-function relationships of classical cannabinoids: CB1/CB2 modulation. Perspect. Med. Chem. 2016, 8, 17-39. [CrossRef]

191. Auwärter, V. JMS Letter. J. Mass Spectrom. 2009, 44, 832-837. [CrossRef]

192. Vardakou, I.; Pistos, C.; Spiliopoulou, C. Spice drugs as a new trend: Mode of action, identification and legislation. Toxicol. Lett. 2010, 197, 157-162. [CrossRef]

193. Dresen, S.; Ferreirós, N.; Pütz, M.; Westphal, F.; Zimmermann, R.; Auwärter, V. Monitoring of herbal mixtures potentially containing synthetic cannabinoids as psychoactive compounds. J. Mass Spectrom. 2010, 45, 1186-1194. [CrossRef]

194. European Monitoring Centre for Drugs and Drug Addiction. European Drug Report 2021: Trends and Developments; European Monitoring Centre for Drugs and Drug Addiction: Lisbon, Portugal, 2021; ISBN 978-92-9497-588-1. ISSN $2314-9086$.

195. Esposito, G.; Scuderi, C.; Valenza, M.; Togna, G.I.; Latina, V.; De Filippis, D.; Cipriano, M.; Carratù, M.R.; Iuvone, T.; Steardo, L. Cannabidiol reduces $\mathrm{A} \beta$-induced neuroinflammation and promotes hippocampal neurogenesis through PPAR $\gamma$ involvement. PLoS ONE 2011, 6, e28668. [CrossRef]

196. O'Sullivan, S.E.; Tarling, E.J.; Bennett, A.J.; Kendall, D.A.; Randall, M.D. Novel time-dependent vascular actions of $\Delta 9-$ tetrahydrocannabinol mediated by peroxisome proliferator-activated receptor gamma. Biochem. Biophys. Res. Commun. 2005, 337, 824-831. [CrossRef]

197. Carrillo-Salinas, F.J.; Navarrete, C.; Mecha, M.; Feliú, A.; Collado, J.A.; Cantarero, I.; Bellido, M.L.; Muñoz, E.; Guaza, C. A cannabigerol derivative suppresses immune responses and protects mice from experimental autoimmune encephalomyelitis. PLOS ONE 2014, 9, e94733.

198. Díaz-Alonso, J.; Paraíso-Luna, J.; Navarrete, C.; Del Río, C.; Cantarero, I.; Palomares, B.; Aguareles, J.; Fernández-Ruiz, J.; Bellido, M.L.; Pollastro, F.; et al. VCE-003.2, a novel cannabigerol derivative, enhances neuronal progenitor cell survival and alleviates symptomatology in murine models of Huntington's disease. Sci. Rep. 2016, 6, 29789. [CrossRef]

199. García, C.; Gómez-Cañas, M.; Burgaz, S.; Palomares, B.; Gómez-Gálvez, Y.; Palomo-Garo, C.; Campo, S.; Ferrer-Hernández, J.; Pavicic, C.; Navarrete, C.; et al. Benefits of VCE-003.2, a cannabigerol quinone derivative, against inflammation-driven neuronal deterioration in experimental Parkinson's disease: Possible involvement of different binding sites at the PPAR $\gamma$ receptor. $J$. Neuroinflammation 2018, 15, 19. [CrossRef] [PubMed] 
200. Rodríguez-Cueto, C.; Santos-García, I.; García-Toscano, L.; Espejo-Porras, F.; Bellido, M.; Fernández-Ruiz, J.; Muñoz, E.; de Lago, E. Neuroprotective effects of the cannabigerol quinone derivative VCE-003.2 in SOD1G93A transgenic mice, an experimental model of amyotrophic lateral sclerosis. Biochem. Pharmacol. 2018, 157, 217-226. [CrossRef] [PubMed]

201. Aguareles, J.; Paraíso-Luna, J.; Palomares, B.; Bajo-Grañeras, R.; Navarrete, C.; Ruiz-Calvo, A.; García-Rincón, D.; García-Taboada E.; Guzmán, M.; Muñoz, E.; et al. Oral administration of the cannabigerol derivative VCE-003.2 promotes subventricular zone neurogenesis and protects against mutant huntingtin-induced neurodegeneration. Transl. Neurodegener. 2019, 8, 9. [CrossRef] [PubMed]

202. Burgaz, S.; García, C.; Gómez-Cañas, M.; Muñoz, E.; Fernández-Ruiz, J. Development of an oral treatment with the PPAR- $\gamma$-acting cannabinoid VCE-003.2 against the inflammation-driven neuronal deterioration in experimental Parkinson's disease. Molecules 2019, 24, 2702. [CrossRef]

203. Hen-Shoval, D.; Amar, S.; Shbiro, L.; Smoum, R.; Haj, C.G.; Mechoulam, R.; Zalsman, G.; Weller, A.; Shoval, G. Acute oral cannabidiolic acid methyl ester reduces depression-like behavior in two genetic animal models of depression. Behav. Brain Res. 2018, 351, 1-3. [CrossRef]

204. Zhu, Y.F.; Linher-Melville, K.; Niazmand, M.J.; Sharma, M.; Shahid, A.; Zhu, K.L.; Parzei, N.; Sidhu, J.; Haj, C.; Mechoulam, R.; et al. An evaluation of the anti-hyperalgesic effects of cannabidiolic acid-methyl ester in a preclinical model of peripheral neuropathic pain. Br. J. Pharmacol. 2020, 177, 2712-2725. [CrossRef]

205. Pertwee, R.G.; Rock, E.M.; Guenther, K.; Limebeer, C.L.; Stevenson, L.A.; Haj, C.; Smoum, R.; Parker, L.A.; Mechoulam, R. Cannabidiolic acid methyl ester, a stable synthetic analogue of cannabidiolic acid, can produce 5-HT1A receptor-mediated suppression of nausea and anxiety in rats. Br. J. Pharmacol. 2018, 175, 100-112. [CrossRef] 